\title{
ON TURBELLARIA AND POLYGORDIUS FROM THE BRAZILIAN COAST
}

\author{
by Eveline du Bois-Reymond Marcus
}

(with 6 plates)

The following descriptions refer to several terrestrial and marine Turbellaria and one Archiannelid. My acknowledgements are due to the National Research Council (Conselho Nacional de Pesquisas) in Rio de Janeiro for contribution to the collecting excursions.

\section{Convoluta cenata, spec. nov. (Fig. 1-7)}

The animals were about $1,5 \mathrm{~mm}$. long alive and are preserved, in oil of cloves, $1 \mathrm{~mm}$. long and $0,5-0,55 \mathrm{~mm}$. broad. When living they are a the little more cuspidate in front than behind; after ccnservation they are anteriorly rounded, posteriorly poinied. The back is convex, the ventral side concave, but the borders are not rolled in.

The opaque body is uniformly green, due to cutaneous algae darker than in C. henseni Böhmig (Marcus 1949, p. 8), and with a bluish hue on the back. This tinge is accomplished by white dots, possibly of guanine, that lie over the algae. A colourless muscular band ( $\mathrm{n}$ ) surrounds the body. Longi) udinal rows of brown glands $(\mathrm{g})$ resemble the pigmented rhabdoids of $C$. illardata (Löhner \& Micoletzky 1911, p. 485; 1911a, p. 411). But while these pseudorhabdites (p. 411) are discharged when the worms are observed under the cover glass and preserved, the brown glands of the present species continue visible in the sections (Fig. 6, 7, g) Further colorific elements of $C$. cenata are the brown ovaries as such are also menticned of C. illardata (1911, p. 485; 1911a, p. 421) 
The dorsal and ventral cilia are about 5 micra long. The epicytium ( $u$ ) of the back is higher (10 micra) than that of the belly (6 micra), while the latter is higher than the former in illardata. The epicytial nuclei of the present species are partly depressed; their diameter is 3-4 micra. The algae (y) have a diameter of 6-12 micra and lie chiefly in the epicytium. They look exactly like those of $C$. henseni, and this smaller species constitutes the principal prey of cenata in our material. But the colour of the algae of the devoured henseni undergoes modifications within the endocytium of cenata, where they are at least in part digested. Therefrom it seems that cenata acquires its epicytial and ectocytial algae by itself.

Glands are abundant, specially cyanophilous ones while they are only moderately numerous in illardata. A huge cluster of frontal glands (f) opens through a minute common pit. The series of brown glands, cyanophilous too, show in sections as very numerous big bottle-shaped glands ( $g$ ) that may be absent in the middle of the ventral side. Yellowish crystalloid crumbling pegs (k), rhabdoids of excretory character, that may be the white dots seen in the living animals, pass through the skin. The posterior end contains some pink glands (e) as such were described of illardata.

The annular cutaneous muscles are strong and when cut transversely appear as vertical streaks principally on the ventral side. The annular muscles of illardata are less developed than the longitudinal ones (1911a, p. 413), while only the bundle of longitudinal marginal fibres $(n)$ that encircles the body is thick in cenata. This bundle passes from one side to the other in front of the frontal glands (f), and behind the male pore (p), so that an anterior and a posterior strand of "transverse" muscles originates. These muscles were described for illardata ( $\mathrm{mt} 1$ and $\mathrm{mt2}$ ), but not their continuation into the equally strong lateral bundle. The annular muscles lie at the basis of the epicytium, the longitudinal fibres belong to the ectocytium. Except a moderate buccal sphincter and somewhat thicker annular fibres the ventral musclature is not specially differentiated. Scme dorso-ventral muscles could be noted in regenerating fragments which can not eat and therefore do not have the inner organs so obscured by food as the complete specimens. 
Eyes are not developed, as little as in C. illardata. The brain (b) is inconspicuous. It lies surrounded by the frontal glands (f) in the ectocytium, and two small ganglia connected by a dorsal commissure can be distinguished. The statocyst is minute and was seen in 2 specimens of the sectioned 30 .

As is described in the following $C$. cenata frequently breaks in two pieces when the eggs are freed, and both fragments may regenerate to complete worms (Fig. 4) By experimental work on Acoela (Keil 1929, p. 238) it is known that the statocyst is not regenerated, and the same seems to happen in the case of the normal regeneration of $C$. cenata. Also the small size of the brain might indicate a regenerated brain. In the experiments ganglia are not restituted. The individuals without statocyst and brain originated under experimental conditions do not behave differently from normal ones.

The mouth $(\mathrm{m})$ lies $0,46 \mathrm{~mm}$. behind the fore end, short before the middle, and may appear as an interruption of the integument where the endocytium containing a vacuole attains the ventral surface. In other sections (Fig. 7) the endocytium has withdrawn and originated a tube lined with epicytium. Some minute erythrophilous gland cells around the mouth were observed. After the description (Löhner \& Micoletzky 1911a, p. 414) one must assume that the mouth of $C$. illardata is very different from that of cenata, but the figures (t. $20 \mathrm{f} .13,14, \mathrm{mu}$ ) do not show "a strongly muscular pharynx as long as one fourth of the body height".

The ectocytium (c) is most distinct in the fragments where the glands are less active and the included food is scarcer The glands ( $g$ ), many nuclei of the epicytium and some algae $(y)$ lie in the loose ectocytium that gradually passes to the endocytium (d).

The endocytium contains a great number of vacuoles, and their contents are Acoela, principally C. henseni, but also smaller C. cenata, and Copepoda. Up to five Acoela were found in the endocytium of one worm. The Acoela are for the most pant digested and absorbed; only a small rest of cyanophilous matter, probably the mucus of the cutaneous glands is ejected through the mouth. The algae of henseni are accumulated in vacuoles, change their colour and are evidently digested. Many bursa-nozzles of henseni remain in the digestive parenchyma of cenata. 
The testes $(t)$ begin at the end of the mass of frontal glands. They lie in the lateral ectocytium somewhat dorsally to the more medial ovarian germ-zones. The spermatogonia and spermatocytes extend backwards on the sides of the body; spermatogonia occur even far behind on the level of the male pore ( $p$ ) that lies $\mathbf{5 0}$ micra in front of the hind end. Spermatids and spermatozoa ( $j$ ) accumulate in the medial part of these lateral strands that comprise the testicular zones of division and growth.

The mature spermatozoa are concentrated in the mid line in a hemispherical limited vacuole of the endocytium. This may be called a seminal vesicle ( $s$ ), although its ectal part contains cyanophilous secretion $(r)$ produced by surrounding glands. The ejaculatory duct or penis (i) is a curved cylindrical tube as in $C$. illardata (1911a, t. 20 f. 15, ap) that communicates by a minute pore with the ectal part of the seminal vesicle. Distinct cilia line the vertical outer portion of the penial tube the anterior wall of which bears a stimulative organ (a) (Westblad 1949, p. 42-43). As was shown by Brauner (1926, p. 36-37) also C. illardata possesses only one "prostatoid" (Hyman 1951, p. 117), the anterior adenodactyl of Löhner \& Micoletzky (1911a, t. 20 f. 15, aa) Like in that species the organ of $C$. cenata has a small lumen lined with a high epithelium and surrounded by muscles. A connection of the latter with the ejaculatory duct where muscles were not observed was not seen. The epithelium of the stimulative organ is nat of glandular character; it rather may store secretion produced by the glands located to the right and left of the point where the organ opens into the ejaculatory duct. The male pore $(p)$ lies at $0,95 \mathrm{~mm}$.

The ovaries (o) uriginate ventrally near the mid line and extend on both sides of the mouth $(\mathrm{m})$ backwards to the level of the female pore (q). They begin behind the testes but not "considerably" farther backwards as in illardata (1911a, p. 420). The oogonia are located in front, the biggest $0,15 \mathrm{~mm}$. long oocytes farther behind and dorsal. Follicle cells and food let the ovaries of cenata appear less homogeneous and compact than those in the diagrams referring to illardata (1911a, textfig. 5 \& 6).

The female pore (q) that lies $0,72 \mathrm{~mm}$. behind the fore end leads to a ciliated vagina $(v)$ that continues as a syncytial vacuolized strand (w) This strand enters the bursal vacuole (h) from 
the front. The $0,1 \mathrm{~mm}$. long spermatozoa in the bursa direct their heads to the vagina and their tails to the nozzle ( $x$ ) The latter is $\mathbf{4 0 - 5 5}$ micra long, begins with cuticular clubs and continues with the usual series of epithelial cells that produce the cuticular lining of the 3 micra wide spermatic duct. The nozzle slopes forward; its ental ovarian end is conical.

Occurrence: Island of São Sebastião, in the plankton near Ilhabela, 160 total specimens and 110 fragments; 13. IV 1954 .

\section{Observations on Convoluta cenata}

The new species is closely related to the smaller and slender C. illardata, but some minor differences, that were mentioned in the preceding description, recommend to maintain the two species separated. Also $C$. henseni Böhmig, that was caught together with cenata, could not be united with $C$. pelagica Löhner \& Micoletzky (1. c.) that was always obtained together with illardata. Both $C$. henseni and $C$. pelagica were also seen independent of $C$. cenata and $C$. illardata respectively. C. henseni and C. cenata behave differently in a laboratory dish. C. henseni has eyes and shows positive phototaxis; $C$. cenata without eyes does not react to light.

C. cenata covers $C$. henseni with its spoon- shaped ventral surface and agitates its fore end with the frontal glands over its prey. Then the cenata stays quiet until the henseni begins to swim away Immediately when the body of henseni loses the contact with the belly of cenata the latter is alarmed and repeats its movements with the frontal pit. The secretion of the glands was not seen. After having suffered two or three of these attacks the henseni stops moving and lies as if it were stuck to the belly of cenata. Then the centre of the ventral surface of the latter deepens for a moment and when the borders of this concavity close again, the henseni is engulfed. The whole process lasts about 30 seconds at a temperature of $25^{\circ} \mathrm{C}$.

Our material comprises relatively few intact specimens. Many of the whole animals have constrictions, fresh wounds or scars. Among the fragments no more thant about 30 are anterior parts, the rest, about $\mathbf{8 0}$, are posterior In some cases the wound is closed by a plug formed by an egg, and though we have not observed ovi- 
position, we infer from the state of our material that the animal breaks when the eggs are freed. Rupture of the tissues followed by fragmentation in consequence of oviposition was observed in Convoluta roscoffensis Graff (Gamble \& Keeble 1904, p. 416). In this species only the anterior end survives, while the posterior fragment after a day of two disintegrates.

C. cenata certainly replaces copulatory organs in the anterior fragment, and frontal glands, mouth, and ovarian germ-zone in the posterior. Indifferent cells that can not be distinguished from spermatogonia and lie all along the outside of the testes might be accountable for the regenerations. As the bipartition occurs in front of the middle and therefore the bulk of these cells is located in the posterior fragment this possibly regenerates better than the anterior This may explain the considerably smaller number of anterior fragments in our collection. Animals with a scar around the body (Fig. 3, z) indicate, that the wound caused by oviposition can also heal without fragmentation.

Fragmentation and regeneration is evidently repeated, because there are worms with a small, statocyst-less, regenerated anterior part and a hind end with incipient copulatory organs. Further there are posterior fragments with recently regenerated, small copulatory organs and a freshly closed anterior border The marginal muscle ring $(n)$ is completed, but the frontal glands are not yet replaced. These cases are examples of regenerating regenerates.

The phenomenon of augmentation in $C$. cenata as a consequence of oviposition is of special interest now that Wager's observation (1913) of asexual reproduction in a South African Convoluta was confirmed (Marcus \& Macnae 1954).

\section{Tricladida Maricola}

Family Procerodidae Diesing 1862

Subfamily Micropharynginae Böhmig 1906

Genus Puiteca, gen. nov.

Flat and narrow Procerodidade with three adhesive lobes on the anterior end and fcur muscular suckers at the hind end. Ovaries situated at the hind end of the pharynx. No bursa. Penis usarmed. 
Type of the genus: Puiteca camica, sp. n.

At first sight Puiteca appears as a quite peculiar form of Triclads due to the anterior adhesive lobes. Also in the inner organization the position of the ovaries behind the pharynx is not known from any other Triclad. It resembles Otomesostoma and Bothrioplana and reveals once more the relationship between the "Alloeocoela Seriata" of the older system and the Tricladida. Until now Centrovarioplana Westblad (1952, p. 46) had the farthest back ovaries among the Tricladida: they lie on the level of the pharynx. Westblad's genus, or subfamily, must be removed from the Procerodidae to the Uteriporidae because of its bursa opening between mouth and male apparatus. Puiteca however with a single genital aperture belongs to the Procerodidae. As I do not want to establish a new subfamily for only one specimen, repeating the characters of the species in the diagnosis of the genus and the subfamily, I place Puiteca provisionally in the Micropharynginae (Bresslau 1933, p. 282). It does not have, it is true, a small pharynx, but the suckers of the hind end and the male apparatus are comparable with Micropharynx parasitica Jägerskiöld (Graff 1912-17, p. 3211) The female apparatus differs by complete reduction of the bursa. In the second species of Micropharynx, M. murmanica Awerinzew (1925, p. 81) the ovaries are located exceptionally far in front, under the brain. Again the male copulatory apparatus is similar to that of Puiteca.

\section{Puiteca camica, sp. n. (Fig. 39-45)}

The only worm has the form of a slender cross with a broad basis. The anterior rim and that of the postcerebral lateral lobes is ruffled, and the basis is provided with two big ventral $(h)$ and two smaller dorsal suckers ( $u$ ) The length in life was about 3 mm., preserved $1,75 \mathrm{~mm}$. In the following the measurements refer to the preserved state. The body is flat and white with a brownish intestine. The small black eyes have a single optic cell; they are situated $0,38 \mathrm{~mm}$. from the tip.

The epithelium has normal nuclei. It is 6 micra high with 3 micra long cilia. The cells contain eosinophilous granules except 
on the sticky, ruffled margins of the three anterior lobes and in the centres of the suckers. In these areas ( $h$ ) the epithelium likens that of the adhesive cells of Nerpa evelinae Marcus (1948, t. 11 f. 71-73) and contains the outlets of parenchymatic eosinophilous glands ( $z$ ) Also the adhesive disc of Bdelloura candida (Wilhelmi 1909, p. 162 t. 4 f. 9) has the same elements as the "Haftzellenring". The hind end of the body has strongly eosinophilous inclusions, chiefly on the ventral side, that are the secretion of the cement glands (c)

The subepidermal circular muscle fibres are fine, the longitudinal ones stronger. Parenchymal muscles are hardly visible due to the development of the testicular and vitellarian follicles. The suckers are provided with numerous longitudinal fibres (1) that insert on the dorsal $(y)$ and ventral side $(x)$ respectively In Bdelloura (Wilhelmi 1909, t. 4 f. 9) the sucker like adhesive area has no re-enforced muscles, therefore its muscles are not specially mentioned in the text.

The mouth $(\mathrm{m})$ lies at the basis of the pharynx, $0,74 \mathrm{~mm}$. from the tip of the body. The cylindrical pharynx (f) is $0,43 \mathrm{~mm}$. long and $0,16 \mathrm{~mm}$. in diameter It has a distinct nervous ring (n) near its outer $\epsilon$ nd and insunk epithelial nuclei. The pharyngeal glands open all on the margin; they are eosinophilous in various shades .

The anterior branch of the intestine $(j)$ has 3 precerebral diverticles on each side and 3-4 (i) behind the brain (b). The posterior limbs (ei) have 9-11 pouches on their outer sides. The diverticles do not anastomose, nor do the posterior limbs behind the genital aperture. Club-shaped cells of Minot are frequent in the main branches and exceptional in the diverticles.

The dorsal testicles ( $t$ ) form numerous, about 100, follicles from the brain to the hind end, leaving free the lateral lobes and suckers and the area above the pharynx. Their ductules unite ventrally on both sides behind the ovaries, and the efferent ducts (d) run to the middle and form one winding spermiducal or false seminal vesicle $(q)$. This enters the intrabulbar, true, muscular seminal vesicle $(k)$ from below and from the front. The vesicle is 50 micra long and 70 micra wide, the penial bulb $0,22 \mathrm{~mm}$. long 
and $0,11 \mathrm{~mm}$. in diameter The ejaculatory duct passes through a granule vesicle $(r)$ with eosinophilous secretion of various tints in its epithelium and opens on the unarmed tip of the muscular penis papilla ( $\mathrm{si}$ ) that is directed backwards. The male antrum (a) surrounds nearly the whole penial papilla. A short duct, the common antrum, leads to the gonopore (p), 80 micra in front of the hind end of the animal. There are great numbers of free sperms in the postpharyngeal parenchyma between the intestinal diverticles and around the vitellaria.

In the sketch of the living animal (Fig. 40) the big ovaries (0), $0,14 \mathrm{~mm}$. in diameter, are situated near the end of the pharynx. In the preserved, clarified worm they lie behind the end. Their germ centre is located in the anterior inner part of the gonad; the oldest ovocytes lie on the outer side near the hind end, where the ovary is connected with the ovovitelloduct $(w)$.

The vitellaria (v) lie ventrally to the testes in the spaces between the intestinal diverticles (i) and ventrally to the latter, extending as far as the testes. The vitelloducts begin over the brain and accompany the inner side of the nerve cords, pass outside the ovaries and the male bulb and unite behind the gonopore. The short common ovovitelloduct (e) is narrow and followed by a likewise short and narrow shell gland duct that rises and opens into the hind end of the male antrum. It is pierced by the outlets of the red shell glands $(\mathrm{g})$

\section{Occurrence and locomotion of Puiteca camica}

One specimen came to the surface in a jar with algae from stones in the upper littoral at Ubatuba (northeastern coast of S. Paulo) in december 1954. Among the algae there were Crustaceans and Prosobranchs, so that the possibility of an ectoparasitic way of life can not be excluded.

The lively animal varied its shape constantly in creeping about, stretched its fore $\in$ nd and fixed it to the substratum, then it moved forward the anterior lobes one after the other, fastened them too and loosed the hind end. The ditaxic movements resemble those of the Polyclads. 


\section{Rhynchodemus ?hectori Graff}

The size of the present worms, up to $12 \mathrm{~mm}$. long and $1 \mathrm{~mm}$. in diameter, agrees with that of the original $R h$. hectori Graff (1899, p. 502; Heinzel 1929, p. 433) from Argentine, and so does its colour, brown ground with two dorsal dark brown stripes.

The glands of the creeping sole are indicated as cyanophilous and eosinophilous (Heinzel 1929, p. 434). In Rh. hectori var. marfa Marcus (1953, p. 46) from the Belgian Congo "numerous cyanophil glands open on the whole length of the sole. Especially in the anterior region the glands penetrate deeply into the parenchyma". The present series shows many diffuse cyanophilous glands but also a concentration of outlets at the beginning of the broad part of the sole.

The strong development of the parenchymal muscles in the present worms corresponds to that in typical hectori (Heinzel, p. 434) and var. marfa.

The male bulb is smaller than in Heinzel's description (1,6 $\mathrm{mm}$.) and in var. marfa $(1,0 \mathrm{~mm}$.), but of the same size $(0,5 \mathrm{~mm}$.) as in hectori var. inopinata (Beauchamp 1930, p. 82 f. 6) from Sumatra. There are no testicular follicles in sections of two of the present specimens; the smaller one has a degenerated male bulb $(0,25 \mathrm{~mm}$. long), and so the bulb of the larger worm may also be reduced, as occurs frequently in Rhynchodemus.

The 60 micra high ventral epithelium of the female antrum ccrresponds to that in typical hectori (Heinzel, p. 435), while it is only 15-16 micra high in var. inopinata and var. marfa.

Occurrence: Terezopolis, State of Rio de Janeiro, National Park. Drs. Claudio and Eudoxia M. Froehlich leg. 4 specimens in june 1952, two of which were immature. One $8 \mathrm{~mm}$. long worm from São Paulo (Horto Florestal) with two pairs of pre-ovarial testes and 1-2 post-ovarial ones has a penial bulb of $0,3 \mathrm{~mm}$.

Rh. samperi Fuhrmann (1914, p. 786) from Colombia that is very similar to $R h$. hectori except in its colour pattern (Heinzel 1929 , p. 433-434) has cyanophilous skin glands all over the body. This detail makes it still more probable that the two species are identical. 
Rhynchodemus schubarti, n. sp. (Fig. 25-31)

External characters: The preserved worms are $6-10 \mathrm{~mm}$. long and up to $0,95 \mathrm{~mm}$. broad, $0,6 \mathrm{~mm}$. high. In a $9,75 \mathrm{~mm}$. long specimen the narrow, ventrally concave anterior end is $1,3 \mathrm{~mm}$. long; the mouth lies $4,8 \mathrm{~mm}$., the genital aperture $6,4 \mathrm{~mm}$. from the tip. The eyes are located at $0,25 \mathrm{~mm}$. The ciliated creeping sole is $0,49 \mathrm{~mm}$. broad, that is half the body breadth. It begins as a narrow furrow that widens suddenly.

The preserved animals are light brown with two dark stripes on the back that may be confluent over the pharynx and are separated by a narrow light zone. In one of the 7 specimens the dark stripes are united in one, and the median light band is wanting. The head is darker also on the ventral side and has white lateral sensory furrows. The anterior and the posterior tip is white. The belly is lighter than the back and the creeping sole nearly white. The eyes are 85 micra in diameter.

Internal characters: The dorsal epithelium measures $20 \mathrm{mi}-$ cra, the ventral 6 micra, with 4 micra long cilia. On the back it is full of eosinophil rhabdites that obscure the intraepithelial nuclei. Only the creeping sole (k) has no rhabdites and shows insunk nuclei. On its entire length there are eosinophilous granules $(h)$ in the mid line. A bundle of cyanophilous glands opens at the beginning of the wide part of the sole. Further cyanophil skin glands (z) are scattered over the surface. The ventral cutaneous nerve plexus (c) is well developed. The subepidermal longitudinal muscle bundles $(\mathrm{m})$ are feeble and are missing above the creeping sole. Also the parenchymal muscles are not strong.

The pharynx is $0.6 \mathrm{~mm}$. long and $0,35 \mathrm{~mm}$. in diameter The anterior limb of the gut has about 25 pairs of diverticles and each of the posterior branches the same number.

The testes (e) begin $2,3 \mathrm{~mm}$. from the tip. There is one pair in front of the ovaries. They end little behind the copulatory organs. The unpigmented follicles are up to $0,12 \mathrm{~mm}$. high and 0,4-0,6 mm. distant from one another The efferent ducts (d) are filled with sperm behind the pharynx. They pierce the tunic of the male bulb (b), bend forwards and upwards, and enter the 
small muscular seminal vesicle ( $s$ ) close beside one another. The seminal vesicle is separated by a short constriction from the following vesicle that receives pale eosinophilous giands. The next portion of the ejaculatory duct $(j)$ is broad and has bright pink glands. The following section has big red glands ( $r$ ) Then comes the broad but low, folded lumen of the male antrum ( $t$ ) It is lined with a flat ( 6 micra) epithelium ( $y$ ) with cilia, and a single layer of circular muscles $(x)$ covered with bundles $(m)$ of longitudinal muscles (together: 20 micra thick) The nuclei of the muscle fibres do not accompany them but form a layer in the surrounding tissue. The antrum has short red glands (f) The whole male duct is enclosed in a bulb (b) of loose muscular tissue that is about $1,1 \mathrm{~mm}$. long and $0,5 \mathrm{~mm}$. in diameter The eosinophilous glands ( $f$ ) are all localized inside this bulb. There is no trace of a false penis papilla.

The common antrum (q) is a vertical, $0,2 \mathrm{~mm}$. long canal, lined by 20 micra high epithelium with basal nuclei, and covered with a muscle layer. On the limit between male antrum and common antrum the female antrum (a) joins from behind.

The ovaries are located $2,9 \mathrm{~mm}$. from the tip. The vitellaria (v) extend farther forward and almost to the hind end of the worm. The ovovitelloducts $(u)$ run above the ventral nerve cords (n) Behind the genital opening (p) they unite, forming a 0,1 $\mathrm{mm}$. long common ovovitelloduct (w) that is directed forward and upward. It is followed by the $0,15 \mathrm{~mm}$. long, narrow gland duct (1), continued into the $0,55 \mathrm{~mm}$. long female antrum (a) that is flat and about $0,1 \mathrm{~mm}$. broad. Its ciliated epithelium is 15 micra high and has a fine cover of muscles. The muscular tunic of the male bulb (b) continues around the female antrum (a) and reaches the female glandular duct.

Occurrence: State of São Paulo, near Pirassununga; 7 specimens in april 1952 and 1954; collected by Drs. Claudio and Eudoxia M. Froehlich. The species is named in honour of our friend Dr. Otro Schubart - Pirassununga, who's hospitality at the Experimental Station of Emas favoured the collecting trips of our Staff. 


\section{Discussion of Rhynchodemus schubarti}

I have compared the present species with all those listed in the discussion of $R h$. scius and could not unite it with any of them. Either colour pattern or antral muscle layers, or the proportions of male, female, and common antrum do not agree with schubarti. $R h$. putzei has a wide glandular duct (= shell chamber). $R h$. hectori Graff is the most similar species. It differs by sole glands along the whole creeping sole; bulbar tunic that does not involve the female antrum; and high ventral epithelium of the latter

Rhynchodemus scius, n. sp. (Fig. 32-38)

External characters: The length of the preserved worms is 7-9 $\mathrm{mm}$., average $7,32 \mathrm{~mm}$., of which the narrow hood occupies 1,3-1,5 (1,37) $\mathrm{mm}$. Breadth 0,7 mm., height 0,5 mm. The eyes lie $0,3-0,5 \mathrm{~mm}$. from the tip; their diameter is $50-80$ (66) micra.

The living worms had a dark greenish gray back with two black stripes (o) flanking a lighter mid line. In the posterior part these stripes are confluent. The ventral side is lighter, the creeping sole almost white. The colour of the preserved worms is brownish or grayish with two more or less distinct dark stripes. The sensory furrow along the sides of the concave hood is white.

The creeping sole begins as a narrow ciliated stripe already in front of the eyes. At its broadening, $1,4 \mathrm{~mm}$. from the tip, there is a salient knob (1) that marks the region of the gland openings forming a localized secretory area.

In an $8,8 \mathrm{~mm}$. long preserved worm the mouth lies $4,5 \mathrm{~mm}$. from the tip; the pharynx is $0,5 \mathrm{~mm}$. long. The gonopore is located at $5,6 \mathrm{~mm}$. In transverse sections of the middle of the body between mouth and gonopore the ciliated creeping sole $(k)$ is about 0,35 $\mathrm{mm}$. broad, that is one half of the body breadth.

Internal characters: The epidermis measures 11 micra on the back, 6 micra on the ventral side, the cilia are 4 micra long. The nuclei are all normal, intraepithelial. The tracts of cyanophilous glands $(h)$ of the sole pour out their secretion on the mentioned area (1) in the beginning of the sole. Farther back there are no 
special sole glands, but cyanophilous skin glands $(z)$ are distributed evenly around the body.

The annular subepidermal muscle layer is simple, the longitudinal fibres are united in bundles (m) 8-12 micra in diametes that are dissolved above the creeping sole $(k)$. The parenchymal muscles (f) are week.

The unpaired anterior branch of the gut (i) is nearly smooth in the hood, behind it has 15-18 pairs of diverticles; the paired posterior limbs have each 24-35 diverticles on their outer sides.

The testes begin on the same level as the ovaries, about 2,1 $\mathrm{mm}$. from the tip. There is a total of up to $\mathbf{1 0}$ follicles irregulariy distributed to bath sides of the body, 4 of which may be postpharyngeal, and 1 or 2 even lie behind the gonopore. The efferent ductules extend farther backwards. In all sectioned specimens the testicular follicles are inconspicuous, the biggest being 70 micra in diameter The testes are not surrounded by pigmented cells.

The narrow efferent ducts (d) contain very little spsrm in the present material. Short in front of the gonopore ( $p$ ) they bend upwards and enter the small muscular seminal vesicle (s) from the sides, abcut $0,1 \mathrm{~mm}$. apart from one another The further course of the male duct is involved in a loose muscular bulb (b), the ental part of which can be evented into the ectal part, thus fcrming a kind of false, not permanent, penis papilla. The ductus ejaculatorius $(j)$ that pierces this papilla is ciliated and goes through a chamber that receives eosinophilous secretion ( $r$ ) The epithelium of the following portion, the wide and folded male antrum (t) has few cilia, while the common (q) and female antrum (a) are well ciliated. The male bulb is $0,42 \mathrm{~mm}$. long and $0,28 \mathrm{~mm}$. in diameter

Of the examined 30 mature worms 14 had a fully developed male organ (Fig. 36) that was everted as false papilla inside the male antrum in 5 cases (Fig. 37) In 12 specimens the male organ (Fig. 38) was reduced (Beauchamp 1930, p. 90; 1952, p. 51; Hyman 1954, p. 2 ) and only 70 micra in diameter In the remaining four it was intermediate between these phases.

The common antrum (q) is a $0,17 \mathrm{~mm}$. long duct with a strong circular and a longitudinal muscle layer 
The ovaries are surrounded by pigmented parenchyma. The vitellaria (v) are well developed. They begin in front of the ovaries and attain the hind end of the worms. The ovovitelloducts run dorso-laterally to the nerve tracts; they unite behind the gonopore. The common ovovitelloduct $(\mathrm{w})$ is $0,14 \mathrm{~mm}$. long. It runs forward and upward and receives the shell glands in the following $70 \mathrm{mi}$ cra long portion. The broad female antrum (a) is $0,17 \mathrm{~mm}$. long and ciliated.

Occurrence: About 50 specimens were collected under bricks on a vacant lot $(40 \times 50 \mathrm{~m})$ at Ubatuba in september 1952 , together with several species of Geoplana, Kontikia orana Froehlich 1955, and Bipalium kewense Moseley 1878. In november 1954 all tricks on the same place were carefully turned over, but: not a single Rhynchodemus was found. It is true that part of the bricks had been taken away and the rest had been trodden into the earth by grazing mules, so that they did not offer as good hiding places as before to the Terricoles.

One specimen was taken at Pirassununga in April 1954 by Dis. Claudio and Eudoxia M. Froehlich in a chicken yard; also together with Kontikia orana and Bipalium kewense; as well as Dolichoplana carvalhoi Corrêa 1947

The greater part (6) of the nine sectioned worms was infe:ted with nematods (length $0,45 \mathrm{~mm}$., diameter $15-20$ micra) in their parenchyma. This infection is not correlated with the sexual phase of the specimens.

\section{Discussion of Rhynchodemus scius}

The copulatory crgans are simple in the genus Rhynchodemus Leidy 1851 (Hyman 1943 emend.) The male apparatus has no true, constant penis papilla; only the muscular antrum may be partially everted and function as penis. The female system has no bursa nor the varicus modalities of genito-intestinal connections. This simplicify reduced the systematic criteria to comparisons between the length of male and female antrum. But in sufficiently numerous materials ( $R h$. nematopsis Beauch.; $R h$. scius) this propcrtion proves highly variable. Dilatations of the male efferent duct (seminal vesicles) and of the female glandular duct (ootype, 
shell chamber) may in part turn out to be functional. The details of the muscle bundles and the sole glands are far from sufficiently known in most species. Heinzel (1929), who stressed the taxonomic importance of the copulatory organs, repeatedly warned against Graff's over-estimation of colour characters. Indeed the varieties of $R h$. hectori Gr. and $R h$. ochroleucus Gr. agree in their copulatory organs but differ in colour, while $R h$. nematoides Lom. and $R h$. nematopsis (Beauch.) as well as $R h$. sylvaticus (Leidy) and $R h$. bilineatus (Mecz.) are examples of different reproductive organs in species with similar colouring. This preamble certainly turns the following review of the species of Rhynchodemus somewhat precarious, but on the other hand I am convinced that $R h$. scius is not identical with any of the previously described species.

\section{Lis of Rhynchodemus-species}

1) amboinensis Graff 1899, p. 499. Amboina. Probably a Rhynchodemus. Up to $40 \mathrm{~mm}$. long alive. Light isabel with gray anterior end; a broad dark median band and two marginal stripes.

2) americanus Hyman 1943, p. 7 U.S.A. Grayish or brownish black above; no stripes. Female antrum twice or more the length of the male canal, and at its posterior end widened into an oval chamber

3) angustus (Hyman 1941, p. 10). Panama. Up to $30 \mathrm{~mm}$. long, preserved. Uniformly black above. Sexual material see Hyman, Am. Mus. Nov. n. ${ }^{\circ}$ 1742, p. 29.

4) aripensis Prudhoe 1949, p. 428. Trinidad. Preserved up to $22 \mathrm{~mm}$. long. Back with 1-3 dark stripes the median conspicuous. Female antrum longer than male one.

5) bilineatus (Mecznikow 1866) Graff 1899, p. 489; Pantin 1950 , p. 32; Hyman 1954, p. 2. Europe. A median dark saddle above the pharynx. Male antrum preceded by two glandular vesicles and decidedly smaller than female antrum (Hyman 1954, p. 6).

6) blainvillei Graff 1899, p. 496. Heinzel 1929, p. 436. Brazil. Back honey yellow without stripes. Female antrum a little longer than the male one. 
7) borellii Graff 1894, p. 4; 1899, p. 503. Paraguay. Generic position uncertain, but as the eyes are somewhat back from the anterior end, possibly a Rhynchodemus. Four indistinctly limited blackish stripes, two median and two lateral ones, on light yellow ground colour

8) bromelicola Beauchamp 1912, p. V Costa Rica. Preserved up to $40 \mathrm{~mm}$. long. Male copulatory organ twice as long as female one.

9) cameliae Fuhrmann 1914, p. 789. Colombia. Evidently with "cephalic hood" (Pantin), and therefore probably a Rhynchodemus. Yellowish with four dark brown stripes, 2 median and 2 marginal ones. Copulatory organs unknown.

10) đaiorchis Fuhrmann 1914a, p. 449. Switzerland. A broad and flat species that is plain ochre on the dorsal and ventral side.

11) graetzi du Bois-Reymond Marcus 1953, p. 69. Panama. Up to $55 \mathrm{~mm}$. long preserved. Back reddish brown to dark gray, without stripes. Male copulatory organ several times as long as female one.

12) hectcri Graff 1897, p. 3; 1899, p. 502. Heinzel 1929, p. 433. Argentine. Ground colour yellowish, obscured by blackish parenchymal pigment that forms two broad or four narrower stripes on the back. Male antrum very much longer and wider than female one.

13) hectori var. incpinata (Beauchamp 1930, p. 81). Sumatra. Dark brown with a broad black median band. Copulatory organs as in typical hectori.

14) hectori var. marfa Marcus 1953, p. 46. Belgian Congo. Back brown, blacki:h gray, or rearly cream coloured, without stripes. Copulatory organs as in typical hectori.

15) ijimai Kaburaki 1922, p. 43. Japan. Back dark olive brown. Female antrum much longer and wider than the male one.

16) maculatus Fuhrmann 1914, p. 788. Colombia. Preserved 30 $\mathrm{mm}$. long. Blackish brown spots over yellowish ground colour Copulatory organs unknown.

17) nematoides Loman 1890; Graff 1899, p. 493. Ceylon; Java. Yellow with four brown stripes; specially the medial ones united by a dark median zone. Female antrum as spacious as male one. 
18) nematopsis (Beauchamp 1930, p. 84) Java. Colour similar to nematoides. Male antrum several times as long as female one and composed of an ental strongly muscular and an ectal duct-like part.

19) oahuensis Hyman 1939a, p. 120. Hawaii. On a pale yellow ground there are two narrow dorsal dark stripes and a very broad dark lateral stripe on each side. Efferent duct and glandular duct opening into a spacious antrum, the wall of which is muscular in the male part.

20) ochroleucus Graff 1899, p. 491 . Bendl 1908, p. 542. Malay Archipelago; Philippines. Ground colour light ochre with 3 grayish brown stripes. Eosinophilous glands open into inner, sinuous part of ejaculatory duct; no seminal vesicle.

21) ochroleucus var. belli Graff 1899, p. 504. Heinzel 1929, p. 439. Amboina. Back light yellow with 4 darker yellow stripes. Copulatory organs as in typical ochroleucus.

22) ochroleucus var. varians Graff 1899, p. 499. Beauchamp 1930, p. 80. Sumatra; Java. Preserved up to $55 \mathrm{~mm}$. long. Light brownish with 3 black stripes, the two lateral being broader than the median one. Copulatory organs as in typical ochroleucus.

23) pellucidus Graff 1899, p. 501. Marcus 1952, p. 72. Brazil. Back with two dark stripes united by a spot behind the pharynx. Female antrum longer than male one. After Heinzel (1929, p. 438) very near blainvillei Gr.

24 ) piptus Marcus 1952, p. 74. Brazil. Likens scius externally Sole with insunk nuclei. Dorso-ventral muscles stronger than in scius. Testicular follicles surrounded by pigmented cells. Withcut antrum masculinum.

25) putzei Graff 1899, p. 494. Prudhoe 1949a, p. 251. Marquesas; Queensland. Back with one dark median stripe. Male bulb lcnger than female efferent part, the glandular duct of which forms a chamber.

26) samperi Fuhrmann 1914, p. 786 . Colombia. Back light brown with 3 black stripes. Male antrum much longer and wider than female one. After Heinzel (1929, p. 433) perhaps identical with hectori Gr. 
27) schmardai Graff 1899, p. 502. Bendl 1908, p. 543. Java, and perhaps other Malay islands. Rusty brown with two narrow umber stripes. Between the long and wide male antrum and the much less developed female one a conspicuous common antrum.

28) stenopus Graff 1894 , p. $4 ; 1899$, p. 495 . Argentine and Venezuela. Eyes as in borellii Gr., therefore probably a Rhynchodemus, but generic position uncertain. Except for the creeping sole uniformly rusty red.

29) sylvaticus (Leidy 1851). Graff 1899, p. 490 . Hyman 1943, p. $5 ; 1954$, p. 2 U.S.A. Grayish or brown above with two longitudinal brown stripes that may be united by a dark spot over the pharynx. Except for a less folded male antrum the copulatory organs are similar to those of scius.

30) vejdovskyi Graff 1899, p. 492. Java; Singapore. Back light yellow or ochre, frequently reddish, with gray median zone and two lateral gray, dark brown or black stripes. Male and female antrum spacious and of equal length. No seminal vesicle. Glandular duct vesicular.

The considerable distance between the anterior tip and the eyes makes it possible that further of Graff's species, specially from the Malay Archipelago, belong to Rhynchodemus. All are, however, distinguished from $R h$. scius by their colour pattern.

\section{Stylochus isifer, sp. n. (Fig. 23-24)}

Preserved worms are up to $6,5 \mathrm{~mm}$. long and $3,8 \mathrm{~mm}$. broad. They are opaque and brown, but these characters are not important if not verified in life. The tentacles $(t)$ are prominent cones containing eyes and lie about $1 \mathrm{~mm}$. behind the anterior margin. The brain (c) is located a little behind the tentacles; it measures $0,2 \mathrm{~mm}$. in length and $0,25 \mathrm{~mm}$. in breadth. The pharynx (f) begins $1,7-1,8 \mathrm{~mm}$. behind the anterior margin and is $2,2-2,8 \mathrm{~mm}$. long. It is less ruffled than in many ather species of the genus, there are only 4-5 side branches on each side. The mouth (b) is slightly anterior to the pharynx middle and to the middle of the body. The male opening lies $0,4 \mathrm{~mm}$, the female orifice $0,3 \mathrm{~mm}$. 
in front of the posterior margin; both open into a common gonopore $(\mathrm{g})$

The band of marginal eyes $(\mathrm{m})$ extends around the anterior half of the body. The peripherical of these eyes are smallest, while the inner ones are up to 35 micra in diameter The tentacular eyes are of very different size, up to about 30 micra. The further eyes are scanty and difficult to distinguish among black stipples. in the parenchyma. They are scattered between brain and marginal eyes and may be called frontal eyes. Distinct groups of cerebral eyes are wanting.

The epidermis is not well preserved. It seems to be equally low on the dorsal and ventral side in the anterior part of the body. The dorsal epidermis is somewhat thickened near the hind end and contains erythrophil granules, as such occur also in other Stylochids (Marcus 1947, p. 104: references)

The testes are very numerous and small; they form a nearly uniform layer on both sides quite near the ventral body wall. The ovaries (o) are dorsal and more medial.

The ectal portions of the efferent ducts (d) are expanded into thin-walled tubes that store sperm, thus forming spermiducal vesicles (Hyman 1953, p. 272) The short terminal portions of these vesicles bend forwards, are empty, and hence their wall is a little thicker Notwithstanding it differs distinctly from the following organ, the seminal vesicle that receives the sperm ducts. separately from behind. The muscular wall of the seminal vesicle is $10-15$ micra thick; the openings of the sperm ducts lie $0,1 \mathrm{~mm}$. apart from one another The vesicle is somewhat constricted in the middle, sharply bent and thus composed of two limbs, an ental dorsal (e) and an ectal ventral one (s). The latter narrows into the ejaculatory duct: that unites with the duct of the granule vesicle. This chambered vesicle $(q)$ is $0,5 \mathrm{~mm}$. long and $0,25-0,3 \mathrm{~mm}$. broad; its epithelium is high and laden with red granules. The wall is about 28 micra thick, and its muscle fibres are accompanied by their nuclei. The unarmed penis papilla is $0,2 \mathrm{~mm}$. long and a little broader at its base. Erythrophil inclusions occur in the epithelium of the male antrum (a)

The female ducts are of the common type of the genus. The uteri (u) are located lateral to the spermiducal vesicles (d) 
They do not contain many eggs and hence are distinct only in the posterior region of the body. The uterine ducts pass through the mass of cement glands $(r)$ and unite opening into the internal vagina (w), dorsal to the tip of the penis papilla. As in other species of the genus only the innermost and the outermost parts of the vagina, the latter the external vagina ( $v)$, are free from cement glands. The epithelium of the external vagina contains red inclusions.

Occurrence: Cananéia, about $200 \mathrm{~km}$. SW of Santos. Seven specimens of different size collected by the Staff of the Oceanographic Institute, São Paulo, in may 1953, on piles of the pier

\section{Discussion of Stylochus isifer}

The new species is the third of the genus verified in the upper littoral of the coast of São Paulo. St. martae Marcus (1947, p. 104), one specimen of which had been the basis of the original diagnosis, was since then taken in a great number, about 50 worms, on the bottom of the boat "Juva" at Cananéia. The animals were, as indicated in the first description, smaller than isifer and white. In addition the efferent ducts unite to a common sperm duct in martae, and the seminal vesicle is evenly curved towards the ventral side, not sharply bent. The second species from our coast, St. ticus Marcus (1952, p. 79), is much bigger than isifer and has two groups. of numerous cerebral eyes. The seminal vesicle of St. ticus is the tripartite type.

With a better knowledge the central american Polycladid fauna shows traces of similarity to that of Brazil (Hyman 1952, p. 196, 199), also the species of Stylochus from this region (Hyman 1939, 1940) were compared with isifer However none has the peculiar bent seminal vesicle characteristic of the new species.

Pseudoceros (Acanthozoon) hispidus, spec. nov. (Fig. 8-12)

The two living worms were clumsy and fragile, about $20 \mathrm{~mm}$. long and $10 \mathrm{~mm}$. broad. Preserved they are 17 and $14 \mathrm{~mm}$. long, $9 \mathrm{~mm}$. broad, and $0,8 \mathrm{~mm}$. high. The borders are rather smooth, only slightly ruffled. The back is covered with small papillae, about 
50 micra high and 60 micra thick, that are sloser se: in the middle than on the sides. The tentacles were longish flaps in life (Fig. 9, r) Preserved they are $1,5 \mathrm{~mm}$. in length and appear as broad and thick folds (Fig. 10) that resemble Stummer-Traunfels' figures 96a and 100a (1933, p. 3540-41)

The colour is a grayish green due to the contents of the gut with whitish borders. The papillae stand as white pricks on the greenish back. The ventral side is white. The eggs in the uteri are pinkish orange.

The tentacular eyes are so numerous that they could not be counted. They lie (Fig. 10) on the dorsal and ventral side and in the basis of the tentacles. In the upper half of the tentacles and in the mid line of the body there are no eyes. The area of the two confluent clusters of cerebral eyes (b) is $0,6 \mathrm{~mm}$. long and 0,5 $\mathrm{mm}$. broad. There are about 40 eyes to each cluster Many scattered frontal eyes occur between the areas of the tentacular and cerebral eyes. The maximum diameter of the cerebral eyes is 50, that of the tentacular eyes 40 micra.

In the larger preserved worm the pharynx (f) is $2,7 \mathrm{~mm}$. long, it begins $26 \mathrm{~mm}$. from the anterior border and ends at $5,3 \mathrm{~mm}$. It has 8-9 deep folds on each side. The mouth $(m)$ is located at $4,1 \mathrm{~mm}$. from the front, a little behind the centre of pharynx. The entrance of the intestine, the "Darmmund", lies $4,8 \mathrm{~mm}$. from the anterior border of the body, that is in front of the hind end of the pharynx, like in $P$. evelinae and contrary to $P$. mopsus (Marsus 1952, p. 92)

The male pore $(\mathrm{n})$ is situated $5,3 \mathrm{~mm}$., the female aperture (o) $6,3 \mathrm{~mm}$. from the front; the sucker ( $\mathrm{x}$ ) with a diameter of 1 $\mathrm{mm}$. and cyanophilous glands lies in the middle of the body.

The main intestine (i) extends backwards to about $14 \mathrm{~mm}$. It gives off numerous lateral branches on different horizontal levels. The ramifications of these branches anastomese frequently and form a dense network (Fig. 10, y). The cells of Minot are restricted to the diverticles of the gut, as in $P$. mopsu. Marc.

The epidermis (Fig. 8 ) is flat, only 8 micra high with a 2 micra thick basement membrane $(z)$. The dorsal epithelium is loose and vacuolized; the ventral epidermis is more regular On both sides there are numerous cyanophilous secretions that come from 
subepidermal glands. Erythrophilous thabdites are very rare on the back, a little more numerous on the ventral side. The papillae (Fig. 8) are similar to those of $P$. micropapillosus Kato (1934, p. 130 ), but the erythrophilous granules of their epithelial cells form vertical strands in the fapillae of the present species. Scme of the papillae are pointed and bent backwards as in Fig. 8 .

The globular testes lie on the ventral side and the large ovaries near the back. The efferent ductules unite to winding swollen effer $\equiv$ nt duits (e) These enter the seminal vesicle ( $t$ ) from behind, one 60 micra distant from the other The seminal vesicle is 0,7 $\mathrm{mm}$. long and $0,5 \mathrm{~mm}$. in diameter with a 70 micra thick muscular wall, the nuclei of which lie between the fibres. The ejaculatory duct $(j)$ is muscular $\div 00$; its nuclei lie outside the muscle layer That is also their position in the mantle of the granule vesicle (q) that is $0,3 \mathrm{~mm}$. long and $0,21 \mathrm{~mm}$. in diameter It is located in front of the seminal vesicle and dorsally to the penis. The ductus granulorum and the ejaculatory duct unite, and the common male duct (d) passes through the short and slender penis papilla. This bears a straight stylet ( $s$ ) that is directed forward, 36 micra wide at its ental end, and $0,125 \mathrm{~mm}$. long (Fig. 12) The ciliated penial sheath $(p)$ has erythrophilous glands on its border It is $0,2 \mathrm{~mm}$. long on its inner side and $0,3 \mathrm{~mm}$. on its outside that is surrounded by the male antrum (a) This is also lined with cilia, and the outermost part of its wall has epidermal character, viz. rhabdites.

From the ovaries the growing oocytes extend to the ventral side. The oviducts that contain sperm are connected with some small spherical uterine vesicles. The epithelial cells of the latter are stuffed with yolk granules. The uteri $(u)$ begin at the level of the sucker and run forward where they unite a little behind the female pore. The uterine eggs show 5 chromosomes. The internal vagina $(v)$ bends to the ventral side and passes through the cement pouch (c) to the external vagina (w) or female antrum, the epithelium of which contains rhabdites.

Occurrence: Island of São Sebastião, two mature specimens among algae (Padina) grown on stones in the upper littoral; 6 . XII. 1953. 


\section{Discussion of Pseudoceros (Acanthozoon) hispidus}

As Pseudoceros Lang (1884, p. 538) comprises 87 species (Marcus 1950, p. 84-88; 1952, p. 93; Licheniplana lepida Heath \& McGregor; Hyman 1953, p. 363-369), every criterion for its further division should be used. I therefore apply Acanthozoon Collingwood (1876, p. 86) as subgeneric name for the present species and the following ones:

P. (A.) armatus (Kelaart 1858; Collingwood 1876, p. 95 ).

$P$. (A.) papilionis (Kelaart 1858; Collingwood, 1. c.) As we already remarked (Marcus 1950 , p. 87), the black dorsal "spines" of this species were not observed by Kaburaki (1923, p. 646) and Palombi (1938, p. 355) Palombi's section (f. 16 on p. 358) ought to have shown cutaneous papillae if they existed. Therewith the position of $\boldsymbol{P}$. papilionis in Acanthozoon becomes uncertain.

$P$. (A.) lepidus (Heath \& McGregor 1912, p. 474) Hyman (1953, p. 370) infers from the description that eyes are absent from the tentacles, and indeed they are said to occur between them (p. 475) This character however cannot be used for the definition of Acanthozoon, because the tentacles bear eyes in the two following species as well as in the here described one. 299

P. (A.) micropapillo us Kato (1934, p. 130); Kato 1944, p.

P. (A.) maculosus Pearse (1938, p. 85); Hyman 1940, p. 485.

None of the previously described species is greenish. The dorsal surface of armatus is dark purple; the back of papilionis is variable, yellow, greyish, even merging to deep purplish brown, with a white cr colourless margin. Its dorsal dots or points are black, while the pricks are white in hispidus. In lepidus and maculosus the cerebral eyes form two clusters, while in micropapillosus and hispidus these groups are not differentiated. The japanese species has a deep vermilion dorsal side with minute white dots and equally white irregular spots.

Eurylepta neptis, spec. nov. (Fig. 13-18)

The animals were up to $28 \mathrm{~mm}$. long and $12 \mathrm{~mm}$. broad alive. Preserved the corresponding measurements were 21 and $13 \mathrm{~mm}$. 
The tentacles ( $r$ ) are nearly contiguous at their bases and curve backwards and outwards in the living worm (Fig. 13) Preserved they are $2,5 \mathrm{~mm}$. long and $0,7 \mathrm{~mm}$. broad at their basis. The margins of the body are undulate.

The colour of the back is orange to reddish brown with darker spots and a dark dorsal median stripe. The borders are lighter, and the ventral side is whitish.

The tentacular eyes, with a maximum diameter of 48 micra, form a dorsal and a ventral group on each side (Fig. 14) Each group comprises about 100 eyes so that the total number may be 400. There are no eyes in the dorsal and ventral mid line, and also the distal half of the tentacles is free of eyes. The cerebral eyes (b) with a diameter of up to 65 micra are disposed in two clusiers that converge anteriorly, but do not meet together There were 88 eyes in the right and 82 in the left cerebral group of the animal drawn in Fig. 14. The cerebral eyes extend over an area that begins $1,2 \mathrm{~mm}$. and ends $2,4 \mathrm{~mm}$. from the anterior border of the body They do not attain the pharynx (f) The brain (h) is $0,28 \mathrm{~mm}$. long, $0,3 \mathrm{~mm}$. broad, and $0,18 \mathrm{~mm}$. thick; it begins 1,75 $\mathrm{mm}$. from the anterior border Some scattered frontal eyes occur between the tentacular and cerebral eyes.

The pharynx (Fig. 16) begins at $2,5 \mathrm{~mm}$. and ends at $5,5 \mathrm{~mm}$. The mouth $(\mathrm{m})$ is located at $2,9 \mathrm{~mm}$. The male pore $(\mathrm{n})$ lies at $5,6 \mathrm{~mm}$., the female opening (o) at $6,9 \mathrm{~mm}$. The sucker $(x)$ is 1 $\mathrm{mm}$. in diameter and situated little behind the centre of the body, at $10 \mathrm{~mm}$. The main intestine (i) ends at $16 \mathrm{~mm}$., that is $2 \mathrm{~mm}$. in front of the hind end of the specimen of which these measurements were taken. The approximative levels of the 4 pairs of intes.inal diverticles are: 6,$2 ; 7,3 ; 8,5$; and $10,1 \mathrm{~mm}$.

The pharynx (f) is bell-shaped, not cylindrical, its root is 0,45 $\mathrm{mm}$., its border $2 \mathrm{~mm}$. in diameter The latter is much folded (Fig. 16) The pharyngeal glands are chiefly cyanophilous and op $\leqq n$ principally on the border, but also on the inner and outer wall. The main intestine (i) gives off 4-5 diverticles that ramify (y) but do not anastomose. Both the intestine and the lateral branchss contain cells of Minot.

The sensory furrow accompanies the anterior border at a distance of $0,4 \mathrm{~mm}$. The dorsal epidermis (Fig. 15) is 84 micra high 
with 6 micra long cilia, the corresponding measurements for the ventral integument are 24 and 8 micra. The basement membrane (z) is $\mathbf{5}$ micra thick. The skin is very rich in glands (Fig. 15), it contains rhabdites ( $\mathrm{k})$, coarse and fine orange granules, and blue vacuoles. The rhabdites are specially numerous on the back and on the belly in front of the sensory furrow, but occur also on the rest of the ventral surface. The sucker has masses of erythrophilous glands.

The testes are ventral, the ovaries dorsal. The efferent ducts, that are not united behind, run on the outer side of the uteri (u) and are widely extended by sperm in their short anterior portion (Fig. 13, e). They bend towards the mid line, become thin and open into the seminal vesicle $(t)$ at $0,25 \mathrm{~mm}$. distance from one another. The spermatozoa are disposed in a peculiar way in this vesicle (Fig. 17) that is $0,8 \mathrm{~mm}$. long and $0,68 \mathrm{~mm}$. in diameter Its muscle mantle is 25 micra thick, and the nuclei lie among the fibres. The granule vesicle (q) is $0,525 \mathrm{~mm}$. long, $0,25 \mathrm{~mm}$. in diameter, and has a 20 micra thick muscular wall with peripherical nuclei. The common male duct (d) $\in$ nters the slender penis papilla that bears a thin stylet (s) $0,17 \mathrm{~mm}$. long and 36 micra thick at its basis (Fig. 18) Many pink glands (pi) open into the penial sheath (p), a $0,33 \mathrm{~mm}$. long fold. The epithelium of the external side of the male antrum (a) contains rhabdites; the male pore $(n)$ is surrounded by a rosette of folds.

The germ zones of the ovaries are dorsal. The uteri (u) extend backwards to the level of about $11 \mathrm{~mm}$. They are not united behind the intestine in opposition to Oligoclado floridanus Pearse (1938, p. 87-89) of which Hymania prytherchi Pearse \& Little: (1938, p. 239) is a synonym (Hyman 1940, p. 489) The two uterine vesicles (ue) of the present species are much smaller than those of E. turma Marcus 1952. The uterine eggs have at least 6 chromosomes. The funther female organs, the internal vagina (v), cement pouch (c), external vagina (w), and outer pore (o) do not show any peculiarities.

Occurrence: Island of São Sebastião, under stones in the upper littoral near Ilhabela (Taquanduva); 4 specimens in the last week of november 1953 . 


\section{Discussion of Eurylepta neptis}

E. cornuta (O. F. Müller 1776) is after Bock (1913, p. 267) possibly the only european species of the genus. Different from neptis are the 7-8 intestinal diverticles in the specimens from St. Malo, Bretagne (Keferstein 1868, p. 10) and their ventral tentacular eyes that are not interrupted in the mid line (1. c., t. 2 f. 3 ) The cerebral eyes of these worms and of those from the Swedish West coast extend over the pharynx. There are about 200 of very different sizes in each cerebral group of the animals from Bohuslän. The unbranched posterior portion of the main intestine is considerably longer than the branched anterior part, and the male pore lies under the pharynx pocket as in E. lobiancoi Lang (1884, p. $579)$ In the mediterranean $E$. cornuta var. melobesiarum Lar:g (1884, p. 576) as well as in Keferstein's material the male pore lies immediately behind the pharynx (p. 577) like in neptis. But also melobesiarum differs from neptis by the cerebral eyes that extend backwards far beyond the brain. The first pair of inte:tinal diverticles bifurcates into an anterior and a lateral branch quite near its origin in melobesiarum and lobiancoi, while it continues undivided for a certain distance in the cornuta from St. Malo and in neptis.

E. lobiancoi Lang (1884, p. 578: lobianchii) is distinguished from neptis by the cylindrical pharynx and the extension of the cerebral eyes backwards far over the pharynx.

E. maculosa Verrill (1893, p. 495); Hyman 1939, p. 150; 1940 , p. 486 . The cerebral eyes continue with numerous frontal eyes between the tenfacles and to the anterior margin of the body The reproductive system is only partially known.

E. cornuta var. wandeli Hallez (1907, p. 2, 7) has less tentasular eyes and a much smaller pharynx than $n \in p t i s$, and folds in the ental part of its granule vesicle. If Hallez description of the only specimen is correct, wandeli must be separated specifically from cornuta.

E. aurantiaca Heath \& McGregor (1912, p. 481); Hyman 1953 , p. 370 . This species has 6-7 intestinal branches, a tubular pharynx, and its stylet ends cut short, not pointed.

E. punctata Kaburaki (1923a, p. 199) is based on a single specimen with extremely short tentacles, a small cylindrical pha- 
rynx, and a minute, conical penis. Only 24-28 cerebral eyes are figured for each cluster (textfig. 7), while neptis has 82-88.

E. leoparda Freeman (1933, p. 138); Hyman 1953, p. 172. There are 6 intestinal diverticles, the tentacular eyes almost meet at the median line. The area occupied by the cerebral eyes is nearly circular, and each group consists of about 30 eyes.

E. susakiensis (Kato 1934, p. 131) has anterior seminal and granule vesicle (like E. turma), a curled male duct (Kato 1944, p. 302), and a cylindrical pharynx (ibid., f. 47), different from the bell-shaped in neptis.

E. turma Marcus (1952, p. 94) is mature in sizes that are quite immature in neptis. Besides the stylet of turma is spiral, and its male vesicles lie before the penis.

Polygordius leo, spec. nov. (Fig. 19-22)

At low-water level of the Island of São Sebastião, between scattered tufts of Padina on stones, in coarse sand with Branchiostoma platae Hubbs, Plagiostomum remanei Marc., Minona tridens Marc., and Microhedyle milaschewitchii (Kow.), we obrained some specimens of Polygordius (Marcus 1954, p. 475) by the washing method of Remane (Ax 1951, p. 333-334) The numerous filaments around the caudal bulb showed the worms immediately to belong to a new species .

The scarce material that we collected consists of one complete worm and fragments, one of which contains sperm, with 4 heads and 3 tails with regenerating cther end. The complete worm was $80 \mathrm{~mm}$. long alive, it has about 200 segments. Press rved it measures $40 \mathrm{~mm}$. in length, $0,5 \mathrm{~mm}$. in maximum diameter, in the growth zone $0,3 \mathrm{~mm}$; length of tentacles (Fig. 19): 0,3 $\mathrm{mm}$.; diameter of caudal bulb $0,46 \mathrm{~mm}$; the up to 15 pygidial appendages are $0,3 \mathrm{~mm}$. long. The length of the segments is $0,2 \mathrm{~mm}$.

The colour is a slightly opalescerst pale pink. There are no eye spots. The skin is quite smooth, the segments are not limited externally. The well developed dorso-lateral ciliated organs do not appear as pits in the sections but as large cushions of high sensory cells (Fig. 22) Skin glands are only recognizable in the 
circle of about 40 adhesive pads around the caudal bulb (Fig. 21). Immediately behind these insent the 8-15 filiform appendages that are epithelial tubes without glands, muscles, or nerves. The anal opening lies on the tip of the bulb. It can appear lobed (Fig. 21).

The mouth cavity is lined with high ciliated epithelium. Ventrally behind the lower lip lies a small pouch with flat cells, the pharyngeal sack, that has a distinct layer of longitudinal fibres, but no muscular bulb. The intestine varies in diameter after its contents and digestive phase. The cilia are of equal length. The food consists of diatoms and detritus. Some of its elements look like muscle fibres and meat juice, though the worms were not baited, so animal food seems to belong to their natural diet. One of the series shows many intracellular stages of an intestinal parasitic protozoon, probably a gregarine. The anus is closed by a strong sphincter muscle.

The ciliated organs (Fig. 22, p) are each provided with a globular ganglion (g), Hempelmann's "Wimpergrubenganglion" (1906, p. 578), protruding into the post-cerebral cavity ( $k$ ) that is separated from the peripharyngeal cavity (c) by the head fold (f) The supra-oesophageal ganglion of $P$. eschaturus (du BoisReymond Marcus 1948, f. 31, o) is represented by a small group of cells dorsally to the intestine on the level of the mouth. Its innervation was not seen.

The dorsal blood vessel that in the most segments runs in the space bei.ween muscle layer and epithelium of the intestine forms a broad sinus over the whole dorsal side of the intestinal tube as in $P$. lacteus (Hempelmann 1906, p. 574) In the latter this sinus occurs only in the fertile segments, while it is present in the most segments of $P$. leo.

\section{Discussion of Polygordius leo and P. e:chaturus}

The new species belongs to the group with pygidial appendages (du Bois-Reymond Marcus 1948, p. 15, no. 8) With its numerous filaments it is quite peculiar. Their insertion near the adhesive gland ring is subterminal like that in appendiculatus Fraip., different from the terminal position in eschaturus d.B.-R. M. 
Like in the latter the caudal appendages are terminal in $P$. madrasensis Aiyar \& Alikunhi 1944, the description of which I could obtain only now, so that it was not compared in my previous paper $\boldsymbol{P}$ madrasensis and $\boldsymbol{P}$. eschaturus differ in size and number of segments, as well as in the number of adhesive glands on the caudal bulb. Moreover the pygidial cirri are relatively longer in madrasensis ( 80 micra in worms of $15 \mathrm{~mm}$. maximum length) than in eschaturus ( 70 micra to $40 \mathrm{~mm}$.)

\section{RESUMO}

Convoluta cenata, sp. n. (Fig. 1-7) do plancton do canal de São Sebastião assemelha-se muito a C. illardata (Löhner \& Micoletzky 1911), sendo diferentes as glândulas e a musculatura. Como C. illardata acompanha C. pelagica Löhn. \& Mic., assim C. cenata foi encontrada juntamente com sua presa, $C$. henseni Böhm. Os ovos de C. cenata são, provàvelmente, libertados por ruptura da parede do corpo. Isto leva, em muitos casos, à bipartição do corpo, e, em geral, as duas partes assim originadas regeneram-se.

Puiteca, gen. nov., com o tipo $P$. camica, sp. n., do litoral de Ubatuba, difere dos outros Tricladida Maricola pelos três lóbulos adesivos e pelos ovários post-faríngeos. Possui átrio genital comum com um único orifício (Procerodidae). Quatro ventosas postericres lembram as Micropharynginae; o aparêlho masculino concorda com o de Micropharynx. O verme locomove-se estendendo o lóbulo mediano que fixa ao substrato. Depois, fixa os lóbulos antero-laterais, um após o outro, e finalmente solta os discos posteriores, aduz o corpo e fixa-se com a parte posierior Possivelmente vive como ectoparasita, mas, foi encontrado num vidro com algas (e Crustáceos e Prosobranchia) subindo ditaxicamente na parede.

Um Rhynchodemus de São Paulo e Terezópolis parece ser Rh. hectori Gr. da Argentina. A esta espécie assemelha-se $R h$. schubarti, sp. n., de Pirassununga, mas as glândulas da sola, a extensão da túnica musculosa do bulbo masculino e o epitélio ventral do átrio feminino são diferentes. Amplo material de $R h$. scius, sp. n., de Ubatuba e de Pirassununga mostra (Fig. 36-38) a variabilidade do aspecto do órgão masculino conforme à fase 
reprodutiva. Rh. piptus Marc. é externamente semelhante, difere, porém, pelos núcleos aprofundados da sola, os músculos dorsoventrais mais fortes, o pigmento ao redor dos testículos e pela ausência de átrio masculino.

Stylochus isifer, sp. n., de Cananéia, caracteriza-se, principalmente, pela vesícula seminal dobrada (Fig. 24, e, s.) St. martae Marc. baseado, em 1947, num único exemplar, foi recebido, em grande número, de Cananéia, do casco de um barco.

Pseudocercs hispidus, sp. n. (Fig. 8-12), encontrado entre Padina no eulitoral de Ilhabela, pertence às espécies de Pseudoceros com papilas dorsais. Convém reunir estas espécies no subgênero Acanthozoon Collingwood 1876 (sinônimo: Licheniplana Heath \&6 McGregor 1912).

Eurylepta neptis, sp. n. (Fig. 13-18) foi obtida perto de Ilhabela, debaixo de pedras no litoral superior A espécie é bem maior que E. turma Marc. e difere desta também nos aparelhos masculino e ferminino.

Polygordius leo, sp. n. (Fig. 19-22) vive na areia grossa da co:ta de Ilhabela, juntamente com Branchiostoma platae Hubbs. Distingue-se de tôdas as outras espécies do gênero pelo grande número de apêndices pigidiais. Dêstes, o máximo até agora conhecido era três ( $P$. ijimai Izuka 1903); $P$. leo tem 15 .

\section{REFERENCES}

AIYAR, R. G. \& ALIKUNHI, K. H. 1944, One some Archiannelids of the Madras Coast. Proc. Nat. Inst. Sci. India v. 10, p. 113-140. Calcutta.

AWERINZEW, S. 1925, Ueber eine neue Art von parasitären Turbellarien. Zool. Anz. v. 64, p. 81-84. Leipzig.

AX, P. 1951, Die Turbellarien des Eulitorals der Kieler Bucht. Zool. Jahrb. Syst. v. 80, p. 277-378. Jena.

BEAUCHAMP, P M. de 1912, Planaires terrestres des Broméliacées de Costa-Rica, etc. Arch. Zool. Expér. Génér. sér. 5 v. 10 Notes et Revue n." 1, p. I-X. Paris.

— 1930, Triclades Terricoles. Arch. Hydrobiol. Suppl. v. 8, p. 72-91. Stuttgart.

__ 1952, Land Planarians from Oceania. Occ. Pap. Bernice $\mathbf{P}$ Bishop Mus. v. 21, n. ${ }^{\circ}$, p. 49-62. Honolulu.

BENDL, W. E. 1908, Beiträge zur Kenntnis des Genus Rhynchodemus. Zeitschr. wiss. Zool. v. 89, p. 524-554 t. 30-31. Leipzig. 
BOCK, S. 1918, Studien über Polycladen. Zool. Bidr. Uppsala v. 2, p. 31-344 t. 3-10. Uppsala.

BöHMIG, L. 1906, Tricladenstudien I. Zeitschr. wiss. Zool. v. 81, p. 344-504 t. 12-19. Leipzig.

du BOIS-REYMOND MARCUS, E. 1948, Further Archiannelids from Brazil. Com. Zool. Mus. Hist. Nat. v. 2 n. ${ }^{\circ} 48$, p. 1-17 t. 1-5. Montevidéu.

1953, Some South American Triclads. Ann. Acad. Brasil. Ciênc. v. 25, p. 65-78. Rio de Janeiro.

BRAUNER, K. 1926, Die Turbellaria acoela, etc. D. Tiefsee-Exped. v. 22 fasc. 2, p. 29-56 t. 3-5. Jena.

BRESSLAU, E. 1933, Turbellaria. W. Kükenthal \& Th. Krumbach, Handb. Zool. v. 2 1st half, p. 52-293, 310-320. Berlin \& Leipzig (Gruyter)

COLLINGWOOD, C. 1876, On thirty-one species of marine Planarians, etc. Transact. Linn. Soc. London ser. 2 Zool. v. 1 pt. 3, p. 83-98 t. 17-19. London.

DIESING, K. M. 1862, Revision der Turbellarien. Abt. Rhabdocoelen. S. Ber. Ak. Wiss. Math. Nat. Cl. v. 45 pt. 1, p. 191-318; 1863, v. 46 , p. $173-188$. Wien.

FREEMAN, D. 1933, The Polyclads of the San Juan Region of Puget Sound. Transact. Americ. Micr. Soc. v. 52, p. 107-146 t. 12-23. Menasha, Wisc.

FuhruanN, O. 1914, Planaires terrestres de Colombie. Mém. Soc. Neuchât. Sci. Nat. v. 5, p. 748-792 t. 15-17 Neuchâtel.

1914a, Zwei neue Landplanarien aus der Schweiz. Rev. Suisse Zool. v. 22, p. 435-456 t. 13 . Genf.

GAMBLE, F. W. \& KEEBLE, F. 1904, The Bionomics of Convoluta roscoffensis, etc. Q. Journ. Micr. Sci. n. ser. v. 47, p. 363431 t. 30-31. London.

GRAFF, L. 1894, Viaggio del dott. Alfredo Borelli, etc. V. Landplanarien. Boll. Mus. Zool. Torino v. 9 n. 182,4 p. Torino.

— 1897, Viaggio nel Chaco Boliviano, etc., IX. Neue Landplanarien. Boll. Mus. Zool. Anat. Comp. Univ. v. 12 n. ${ }^{\circ} 296$, p. 1-3. Torino

- 1899, Monographie der Turbellarien- II. Tricladida Terricola. v. 1, XIII + 574 p., v. 2, 58 t. Leipzig (Engelmann)

1912-1917, Turbellaria Tricladida. Bronn, Kl. Ord. TierReichs v. 4, Abt. I c, p. I-XXXVII, 2601-3369 t. 31-64. Leipzig.

HALlEZ, P. 1907, Polyclades et Triclades maricoles. Expéd. Antarct. Franç. (1903-05) Dr. J. Charcot. Sci. Nat. Doc. Sci. Vers, p. 1-26 t. 1-7 Paris.

HEATH, H. \& McGREGOR, E. A. 1912, New Polyclads from Monterey Bay, California. Proc. Ac. Nat. Sci. Philad. v. 64, p. 455488 t. 12-18. Philadelphia, Pa. 
HEINZEL, L. 1929, Zur Kenntnis der Rhynchodemiden. Zool. Jahrh. Syst. v. 56, p. 425-462 t. 11-12. Jena.

HEMPELMANN, F. 1906, Zur Morphologie von Polygordius, etc. Zeitschr. wiss. Zool. v. 84, p. 527-618 t. 25-29. Leipzig.

HYMAN, L. H. 1939, Some Polyclads of the New England Coast, etc. Biol. Bull. v. 76, p. 127-152. Woods Hole, Mass.

1939a, Land Planarians from the Hawaiian Islands. Arch. Zool. Expér. Génér. v. 80 Notes et Revue n.' 3, p. 116-124. Paris.

1940, The Polyclad Flatworms of the Atlantic Coast, etc. Proc. C S. Nat. Mus. v. 89 n.' 3101, p. 449-495. Washington, D C.

— 1940a, Land Planarians from the Palau and Caroline Islands, Micronesia. Ann. Mag. Nat. Hist. ser. 11 v. 5, p. 345-362. London.

_ 1941, Terrestrial Flatworms from The Canal Zone, Panama. Am. Mus. Novit. n. ${ }^{0} 1105$, p. 1-11. New York.

- 1943, Endemic and Exotic Land Planarians in the United States, etc. Am. Mus. Novit. n." 1241, p. 1-22. New York.

1951, The Invertebrates: Platyhelminthes and Rhynchocoela. $\mathrm{V}+550$ p. 208 fig. New York, etc. (McGraw-Hill)

1952, Further Notes on the Turbellarian Fauna of the Atlantic. Coast of the United States. Biol. Bull. v. 103, p. 195-200. Lancaster, Pa.

- 1953, The Polyclad Flaiworms of the Pacific Coast of North America. Bull. Am. Mus. Nat. Hist. v. 100 art. 2, p. 265-392. New York.

1954, Some Land Planarians of the United States and Europe, with Remarks on Nomencla!ure. Am. Mus. Novit. n. ${ }^{\circ}$ 1667, p. 1-21 New York.

IZUKA, A. 1903, A new Polygordius from Misaki, etc. Annot. Zool. Jap. v. 4, p. 137-139. Tokyo.

KABURAKI, T. 1922, On the Terrestrial Planarians from Japanese Territories. Journ. Coll. Sci. Inı. Univ. Tokyo v. 44 n. ${ }^{\circ}$ 4, p. 1-54 t. 1. Tokyo.

1923, The Polyclad Turbellarians from the Philippine Islands. Smithson. Inst. U. S. Nat. Mus. Bull. 100 v. 1 pt. 10, p. 635-649 t. 53-54. Washington, D. C.

- 1923a, Notes on Japanese Polyclad Turbellarians. Annot. Zool. Jap. v. 10 n. 19, p. 191-201. Tokyo.

KATO, K. 1934, Polyclad Turbellarians from the Neighbourhood of the Mitsui Insti:ute, etc. Jap. Journ. Zool. v. 6 n. ${ }^{\circ}$, p. 123138 t. 1. Tokyo.

1944, Polycladida of Japan. Journ. Res. Inst. Nat. Resourc. v. 1 n. ${ }^{\circ} 3$, p. 257-318 t. 26-29. Tokyo. 
KEFERSTEIN, W. 1868, Beiträge. Seeplanarien von St. Malo. Abh. Kgl. Ges. Wiss. Gött. v. 14, p. 1-38 (of the copy) t. 1-3. Göttingen.

KEIL, E. M. 1929, Regeneration in Polychoerus caudatus Mark. Biol. Bull. v. 57, p. 225-244. Woods Hole, Mass.

LANG, A. 1884, Polycladen. Fauna \& Flora. Neapel. Monogr. 11, IX +688 p. 39 t. Leipzig.

LÖHNER, L. \& MICOLETZKY, H. 1911, Convoluta pelagica, n. sp. \& Monochoerus illardatus, n. g., n. sp., etc. Zool. Anz. v. 37, p. 481-486. Leipzig.

- 1911a, Ueber zwei neue pelagische Acoelen, etc. Zeitschr. wiss. Zool. v. 98, p. 381-429 t. 19-20; Leipzig.

MARCUS, E. 1947, Turbellarios marinhos do Brasil. Bol. Fac. Fil.,

Ci. Letr. Zoologia n.“ 12, p. 99-215 t. 1-21. São Paulo.

— 1948, Turbellaria do Brasil. Bol. Fac. Fil., Ci. Letr. Zoologia n. 13, p. 111-243 t. 1-20. São Paulo.

_ 1949, Turbellaria Brasileiros 7. Bol. Fac. Fil., Ci. Letr. Zoologia n. ${ }^{\circ}$ 14, p. 7-156 t. 1-22. São Paulo.

- 1950, Turbellaria Brasileiros 8. Bol. Fac. Fil., Ci. Letr. Zoologia n." 15, p. 5-191 t. 1-34. São Paulo.

— 1952, Turbellaria Brasileiros 10. Bol. Fac. Fil., Ci. Letr. Zoologia n." 17, p. 5-187 t. 1-32. São Paulo.

— 1953, Turbellaria Tricladida. Inst. Parcs Nat. Congo Belge. Upemba. I. Miss. Witte fasc. 21, p. 1-62. Bruxelles.

1954, Turbellaria Brasileiros 11. Pap. Avulsos Dep. Zool. Secr. Agricult. v. 11, n.' 24, p. 419-489. São Paulo.

- \& MACNAE, W. 1954, Architomy in a species of Convoluta. Nature v. 173, p. 130. London.

MEIXNER, J. 1921, Rhynchodemus peneckei, ein Landtriclade aus Steiermark. Zool. Jahrb. Syst. v. 44, p. 355-374 t. 19. Jena.

PAlombI, A. 1938, Turbellari del Sud Africa. Arch. Zool. Ital. v. 25, p. 329-383 t. 9. Torino.

PANTIN, C. F. A. 1950, Locomotion in british terestrial Nemertines and Planarians, etc. Proc. Linn. Soc. London Sess. 162 (194950) pt. 1, p. 23-37 t. 1-2. London.

PEARSE, A. S. 1938, Polyclads of the East Coast of North America. Proc. U. S. Nat. Mus. v. 86 n. ${ }^{\circ}$ 3044, p. 67-98. Washington, D. C.

— \& LITTLER, J. W 1938, Polyclads of Beaufort, N. C. Journ. Elisha Mitchell Sci. Soc. v. 54, p. 235-244 t. 20-23. Chapel Hill, N. C.

PRUDHOE, S. 1949, Some Roundworms and Flatworms from the West Indies and Surinam. IV Land Planarians. Linn. Soc. Journ. Zool. v. 41 n.• 281, p. 420-433. London. 
_ 1949a, Some Land Planarians from the Marquesas Islands. Occ. Pap. Bernice P. Bishop Mus. v. 19 n.' 13, p. 247-255. Honolulu.

StUmmer-TraUnfels, R. v. 1933, Polycladida. Bronn, Kl. Ordn. v. 4, Att. I c, p. 3485-3598 t. 1. Leipzig.

VERRILL, A. E. 1893, Marine Planarians of New England. Transact. Connect. Ac. Arts \& Sci. v. 8 n. ${ }^{\circ}$ 24, p. $459-520$ t. 40-44. New Haven, Conn.

WAGER, H. A. 1913, Some observations on Convoluta roscoffensis. Rep. S. Afr. Ass. Adv. Sci. v. 10, p. 223-225. Cape Town.

WESTBLAD, E. 1949, Studien über skandinavische Turbellaria Acoela V. Ark. Zool. v. 41 A n." 7, p. 1-82 t. 1. Stockholm.

— 1952, Turbellaria (excl. Kalyptorhynchia) Further Zool. Res. Swed. Antarct. Exp. 1901-03 v. 4 n. ${ }^{\circ}$, 55 p. Stockholm. WILHELMI, J. 1909, Tricladen. Fauna \& Flora. Neapel. Monogr 32 , XII + 405 p. 16 t. Berlin. 


\section{PLATE 1}

Figures 1-7: Corvoluta cenata, sp. n.

Fig. 1 - Living worm, slightly compressed. The rows of glands (g) drawn only in the anterior part.

Fig. 2 - Worm swimming.

Fig. 3 - Total mount in ventral view of animal with scar from expelled egg.

Fig. 4 - Anterior and posterior fragments short after breaking and some time later

Fig. 5 - Ventral view of total mount with muscle ring.

Fig. 6 - Combined median section of hind end.

Fig. 7 - Combined horizontal section.

a - stimulative organ. b - brain. c - ectocytium. d - endocytium. e - erythrophilous glands. $\mathrm{f}$ - frontal pit and glands. $\mathrm{g}$ - cyanophilous skin glands. $\mathrm{h}$ - bursa. $\mathrm{i}$ - ejaculatory duct. $\mathrm{j}$ - sperm. $\mathrm{k}$ - yellowish granules. $\mathrm{m}$ - mouth. $\mathrm{n}$ - muscle ring. o - ovary $\mathrm{p}$ - male pore. $\mathrm{q}$ - female pore. $\mathrm{r}$ - cyanophilous secretion of the seminal vesicle. $s-$ seminal vesicle. $t-$ testes. $\mathrm{u}$ - epicytium. $\mathrm{v}$ - vagina. $\mathrm{w}$ - syncytial part of vagina. $x$ - nozzle of bursa. $y$ - algae. $z$ - scar from oviposition.

Fig. 8 - Pseudoceros (Acanthozoon) hispidus, sp. n., sagittal section of dorsal papilla. Lettering see Plate 2 
E. du BOIS - REYMOND MARCUS - TURBELlaRIA - PLATE 1

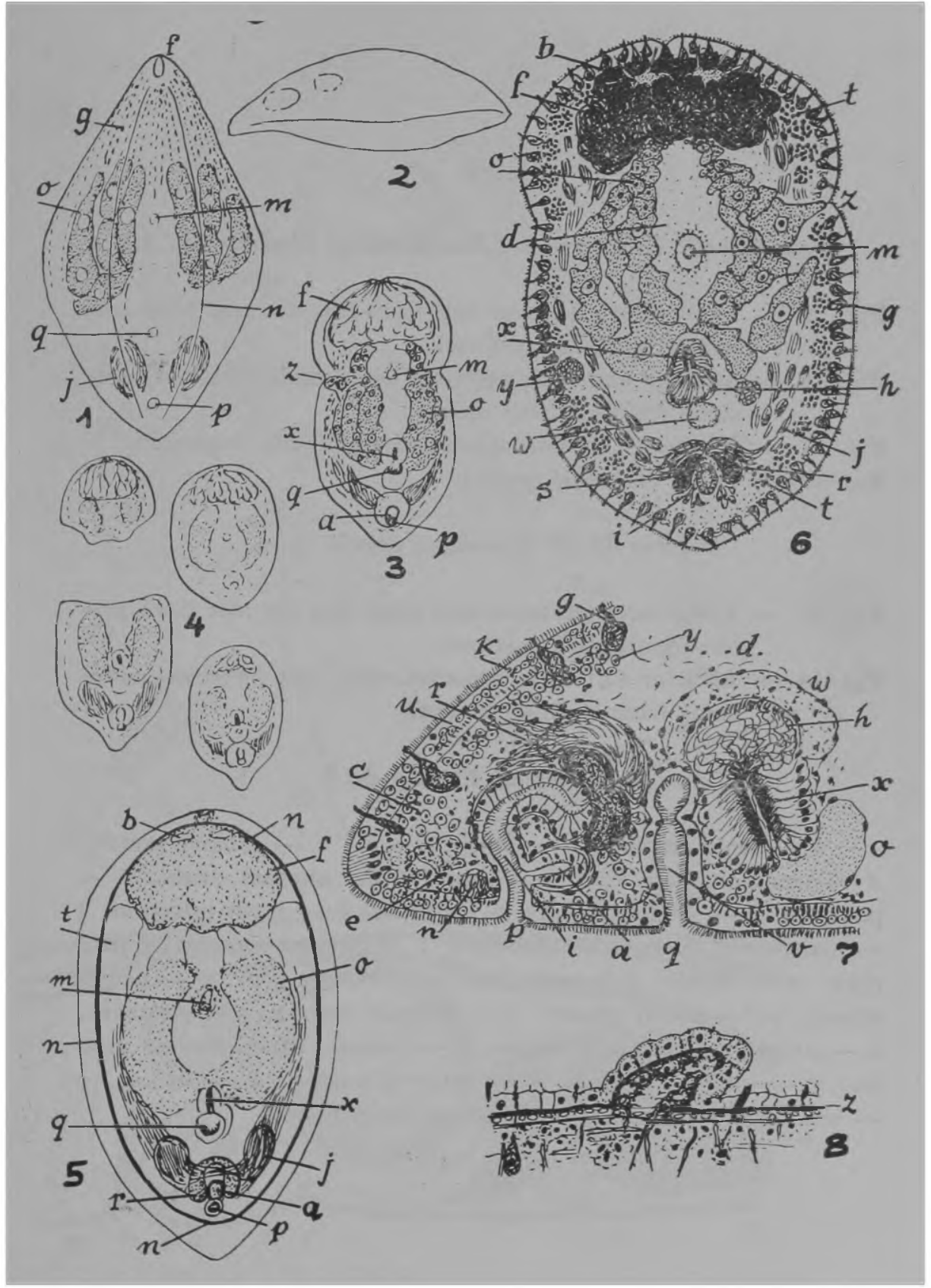




\section{PLATE 2}

Figures 9-12: Pseudoderos (Acanthozoon) hispidus, sp. m.

Fig. 9 - Total view. Anterior end from life, the rest from preserved, clarified specimen.

Fig. 10 - Anterior end with tentacles, eyes, and intestinal branching from clarified mount.

Fig. 11 - Combined median section of copulatory organs.

Fig. 12 - Stylet on penial papilla.

Figures 13-14: Eurylepta neptis, sp. n.

Fig. 13 - Total view. Anterior end from life, the rest from preserved, clarified specimen.

Fig. 14 - Anterior end with tentacles, eyes, and intestinal branching from clarified mount.

\section{Lettering of Figures 8-17}

a - male antrum. b - cerebral eyes. c - cement pouch . d - common male duct. e - one of the efferent ducts. f pharynx. g - cement glands. $\mathrm{h}$ - brain. $\mathrm{i}$ - main intestine. $\mathrm{j}$ - ejaculatory duct. $\mathrm{k}$ - rhabdites. 1 - circular muscles of pharynx. $\mathrm{m}$ - mouth. $\mathrm{n}$ - male pore. o - female pore. $\mathrm{p}$ - penial sheath. pi - penial glands. $\mathrm{q}-$ granule vesicle. $\mathrm{r}$ - tentacle. $\mathrm{s}$ - stylet. $\mathrm{t}$ - seminal vesicle. $\mathrm{u}$ - uterus. ue - uterine vesicle. $\mathbf{v}$ - internal vagina. $w$ - external vagina. $\mathbf{x}$ - sucker. $\mathbf{y}$ - intestinal branches. $\mathrm{z}$ - basement membrane. 
E. du BOIS - REYMOND MARCUS - TURBEllaria - Plate 2

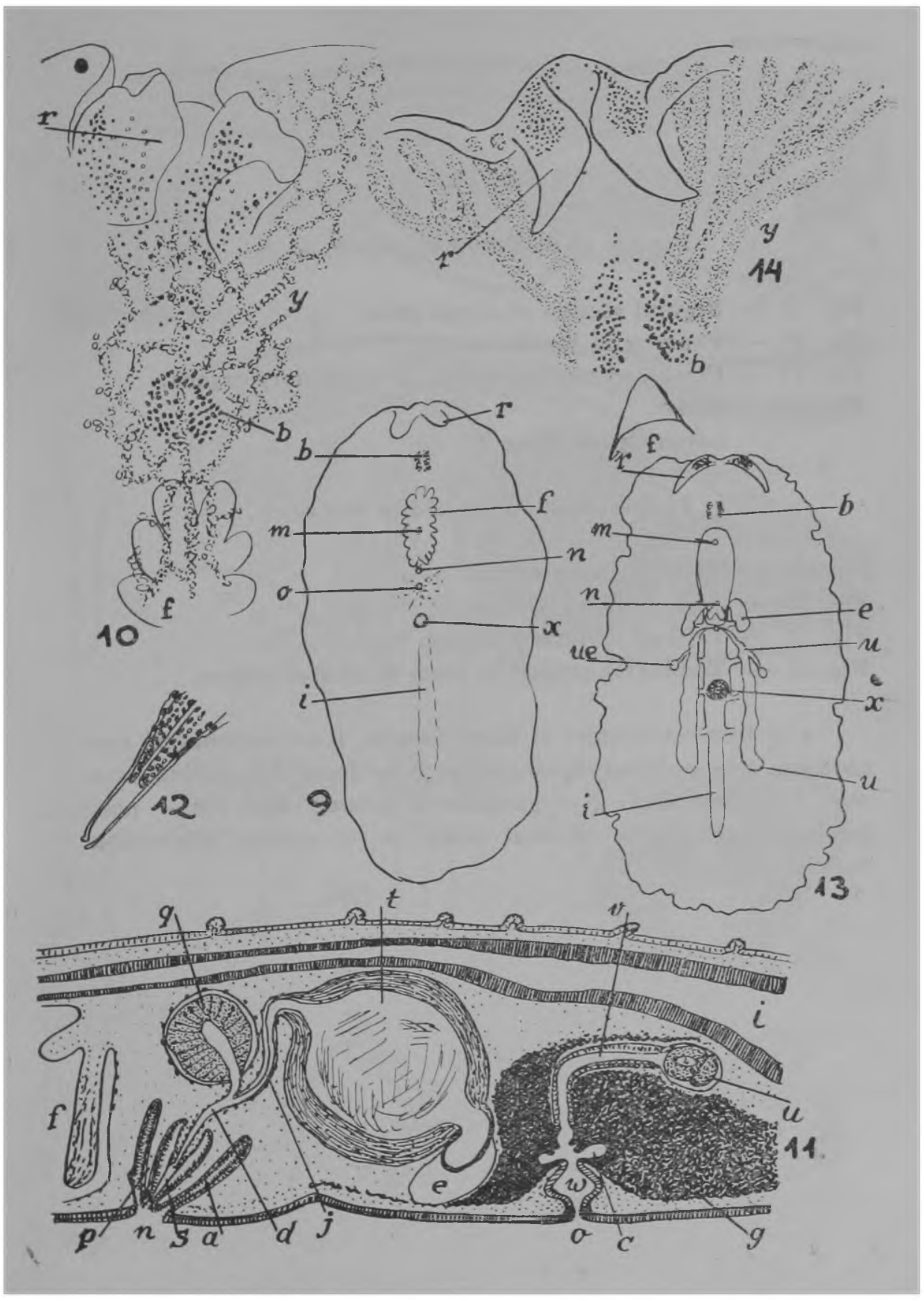




\section{PLATE 3}

Figures 15-8: Eurylepta neptis, sp. n.

Fig. 15 - Sagittal section of dorsal skin.

Fig. 16 - Pharynx in sagittal section.

Fig. 17 - Combined median section of copulatory organs.

Fig. 18 - Stylet.

Lettering see Plate 2 .

Figures 19-22: Polygordius leo, sp. n.

Fig. $19-$ Head of living worm.

Fig. 20 - Tails of living worms.

Fig. 21 - Tails of preserved worms.

Fig. 22 - Transverse section on level of ciliated organs.

a - first commissure of blood vessels . b - oesophageal connectives. $\mathrm{c}$ - peripharyngeal cavity $\mathrm{d}$ - dorsal longitudinal muscles. $\mathrm{f}$ - head fold. $\mathrm{g}$ - ganglion of ciliated organ. $\mathrm{k}$ - pos:cerebral cavity. p - ciliated organ. v - ventral longitudinal muscle. 
E. D. B.-R. MIARCUS - TURBELLARIA \& POLYGORDIUS - PLATE 3
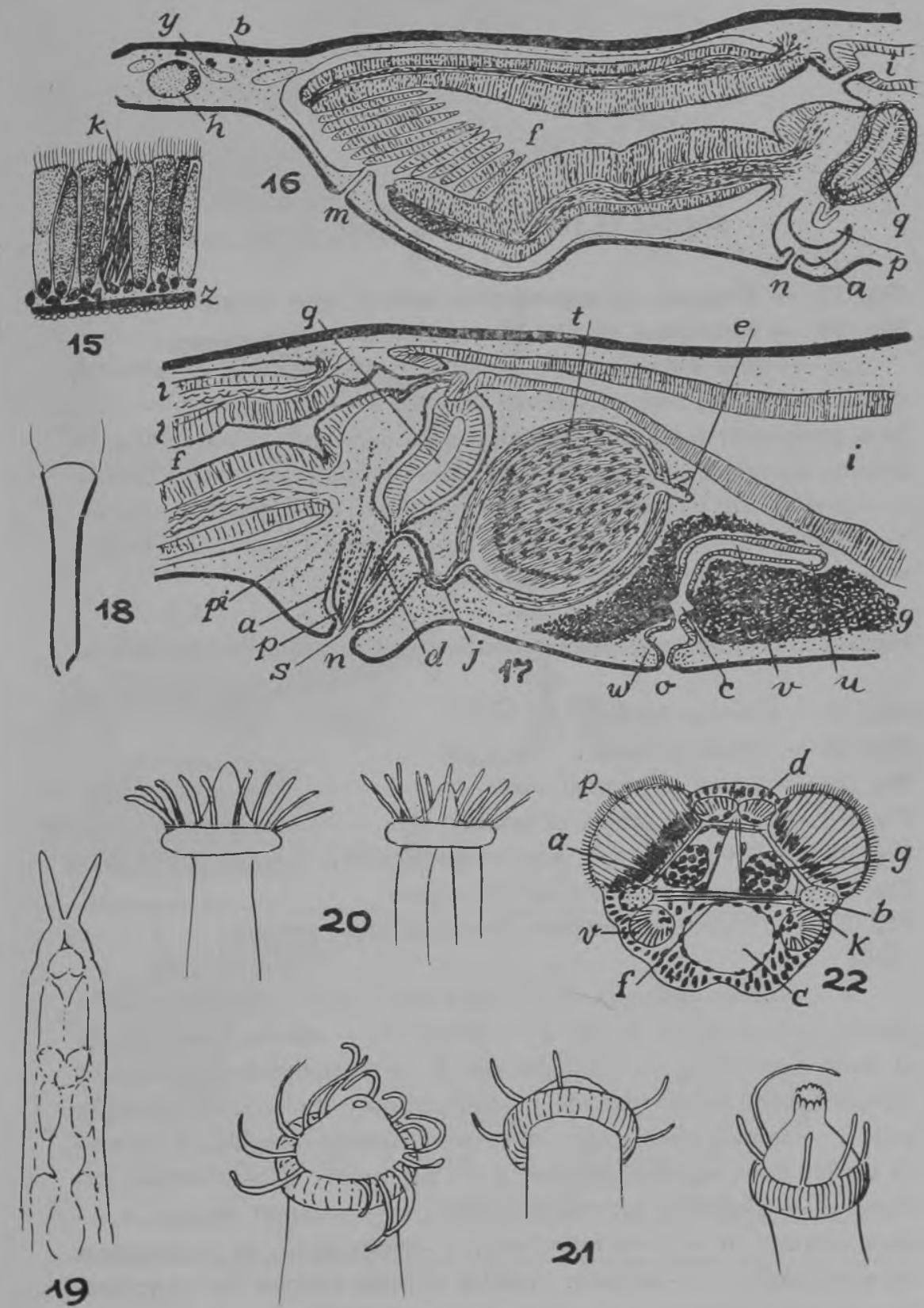


\section{PLATE 4}

Figures 23-24: Stylochus isifer, n. sp.

Fig. 23 - Diagram of organisation; size of eyes exaggerated.

Fig. 24 - Combined section of copulatory organs.

a - male antrum. b - mouth. c - brain. d - efferent ducts. e - ental limb of seminal vesicle. $f$ - pharynx. $g$ - common gonopore. $\mathrm{h}$ - pharyngeal pouch. $\mathrm{i}$ - gut. $\mathrm{j}$ - uniting of uterine ducts. $\mathrm{m}$ - marginal eyes. $\mathrm{n}$ - submuscular nerve plexus. o - one of the ovaries. $\mathrm{p}$ - penis papilla. q - granule vesicle. $\mathrm{r}$ - cement glands. $\mathrm{s}$ - ectal limb of seminal vesicle. $\mathrm{u}$ - uteri. $\mathrm{v}$ - external vagina. $\mathrm{w}$ - internal vagina.

Figures 25-31: Rhynchodemus schubarti, sp. n., preserved specimens.

Fig. 25 - Dorsal view

Fig. 26 - Head of same.

Fig. 27 - Same in ventral view

Fig. 28 - Colour pattern of back.

Fig. 29 - Pre-pharyngeal transverse section.

Fig. 30 - Diagram of copulatory organs .

Fig. 31 - Transverse section of wall of male antrum.

a - female antrum. b - male bulb. c - cutaneous nerve plexus. d - efferent ducts. e - testes. f - eosinophilous glands of male antrum. $\mathrm{g}$ - shell glands. $\mathrm{h}$ - eosinophilous glands of creeping sole. $\mathrm{i}$ - intestine. $\mathrm{j}$ - ejaculatory duct. $\mathrm{k}$ - creeping sole. 1 - female gland duct. $\mathrm{m}-$ longitudinal muscles. $\mathrm{n}-$ nerve cords. o - pigment stripes. $\mathrm{p}$ - gonopore. $\mathrm{q}$ - common antrum. $r$ - glands of ejaculatory duct. $s$ - seminal vesicle. $t-$ male antrum. $\mathrm{u}$ - ovovitelloducts. $\mathrm{v}$ - vitellaria. $\mathrm{w}$ - common ovovitelloduct. $x-$ annular muscles of male antrum. $y-$ epithelium of male antrum. $z$ - cyanophilous skin glands. 
E. du BOIS - REYMond MARCUS - TURbEllaria - Plate 4

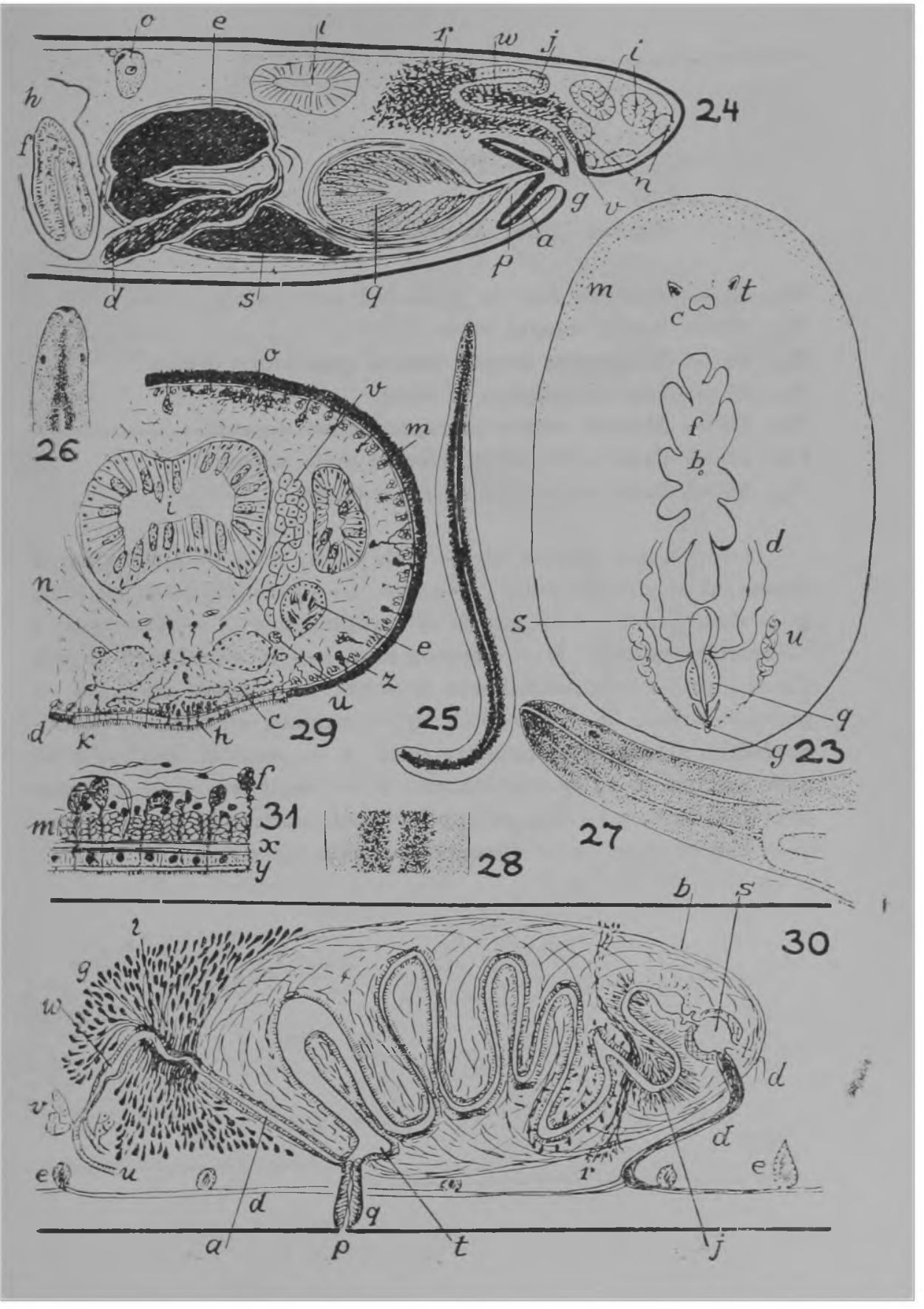




\section{PLATE 5}

Figures 32-38: Rhynchodemus scius, sp. n.

Fig. 32 - Anterior end of preserved worm, dorsal view

Fig. 33 - Same, ventral view.

Fig. 34 - Transverse section behind copulatory organs.

Fig. 35 - Sagittal diagram of head.

Fig. 36 - Median section of reproductive organs.

Fig. 37 - Same with partly everted male antrum.

Fig. 38 - Same with reduced male organ.

a - female antrum. b - male bulb. c - cutaneous nerve plexus. d - efferent ducts. e - eye. f - parenchymatic muscles. $\mathrm{g}$ - shell glands. $\mathrm{h}-$ glands of creeping sole. $\mathrm{i}$ - intestine. $\mathrm{j}$ - ejaculatory duct. $\mathrm{k}$ - creeping sole. 1 - localized area of sole glands. $\mathrm{m}$ - longitudinal skin muscles. $\mathrm{n}$ - nerve cords. o pigment stripes. $\mathrm{p}-$ gonopore. $\mathrm{q}-$ common antrum. $\mathrm{r}-$ eosinophilous glands of ejaculatory duct. $s-$ seminal vesicle. $t-$ male antrum. $\mathrm{u}$ - ovovitelloducts. $\mathrm{v}$ - vitellaries. $\mathrm{w}-$ common ovovitelloduct. $\mathrm{x}$ - beginning of eversible portion of male antrum. $\mathbf{v}$ - end of same. $z$ - cyanophilous skin glands. 
E. du BOIS-REYMOND MARCUS - TURBEllaria - Plate 5

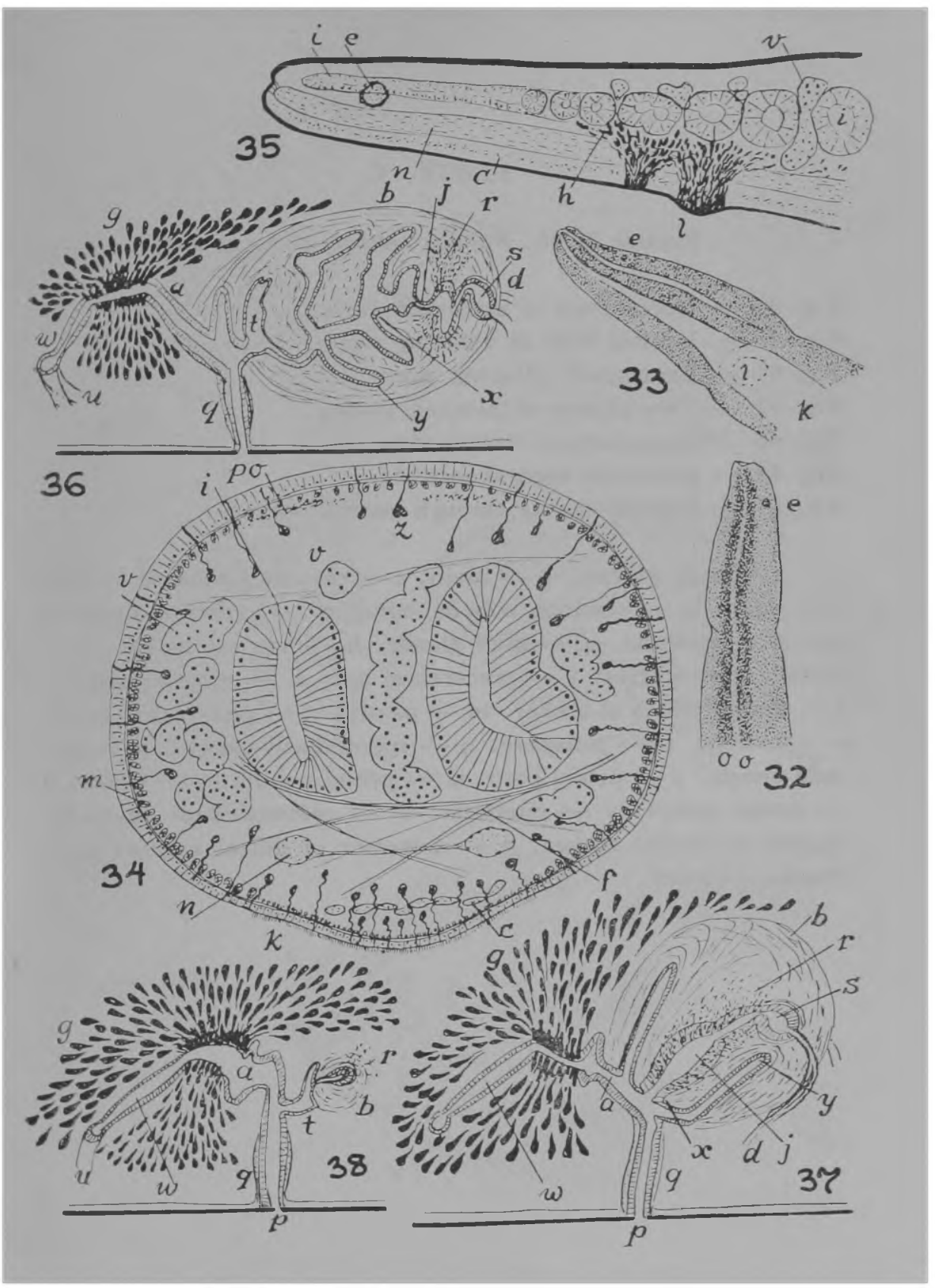




\section{PLATE 6}

Figures 39-45: Puiteca camica, g. n., sp .n.

Fig. 39 - Dorsal view of expanded worm.

Fig. 40 - Ventral view of adhering worm.

Fig. 41 - Contracted adhering worm.

Fig. 42 - Two phases of creeping worm.

Fig. 43 - Organization, ventral view.

Fig. 44 - Combined sagittal sections.

Fig. 45 - Sagittal section through ventral sucker

a - male antrum. b - brain. c - cement glands. d - efferent ducts. e - common ovovitelloduct, ei - posterior limbs of gut. $\mathrm{f}$ - pharynx. $\mathrm{g}$ - shell glands. $\mathrm{h}$ - ventral sucker $\mathrm{i}$ intestinal diverticles. $\mathbf{j}$ - precerebral gut. $\mathbf{k}$ - seminal vesicle. 1 - muscle fibres of sucker $\mathrm{m}$ - mouth. $\mathrm{n}$ - pharyngeal nerve. o - ovaries. $\mathrm{p}$ - gonopore. $\mathrm{q}$ - spermiducal vesicle. $\mathrm{r}$ - granule vesicle. $s-$ penial bulb. si - penial papilla. $t-$ testes. $u$ - dorsal sucker $\mathrm{v}$ - vitellaria. $\mathrm{w}$ - ovovitelloduct. $\mathrm{x}$ - retractor of ventral sucker. y - retractor of dorsal sucker. z glands of sucker 
E. du BOIS - REYMOND MARCUS - TURBEllaria - Plate 6

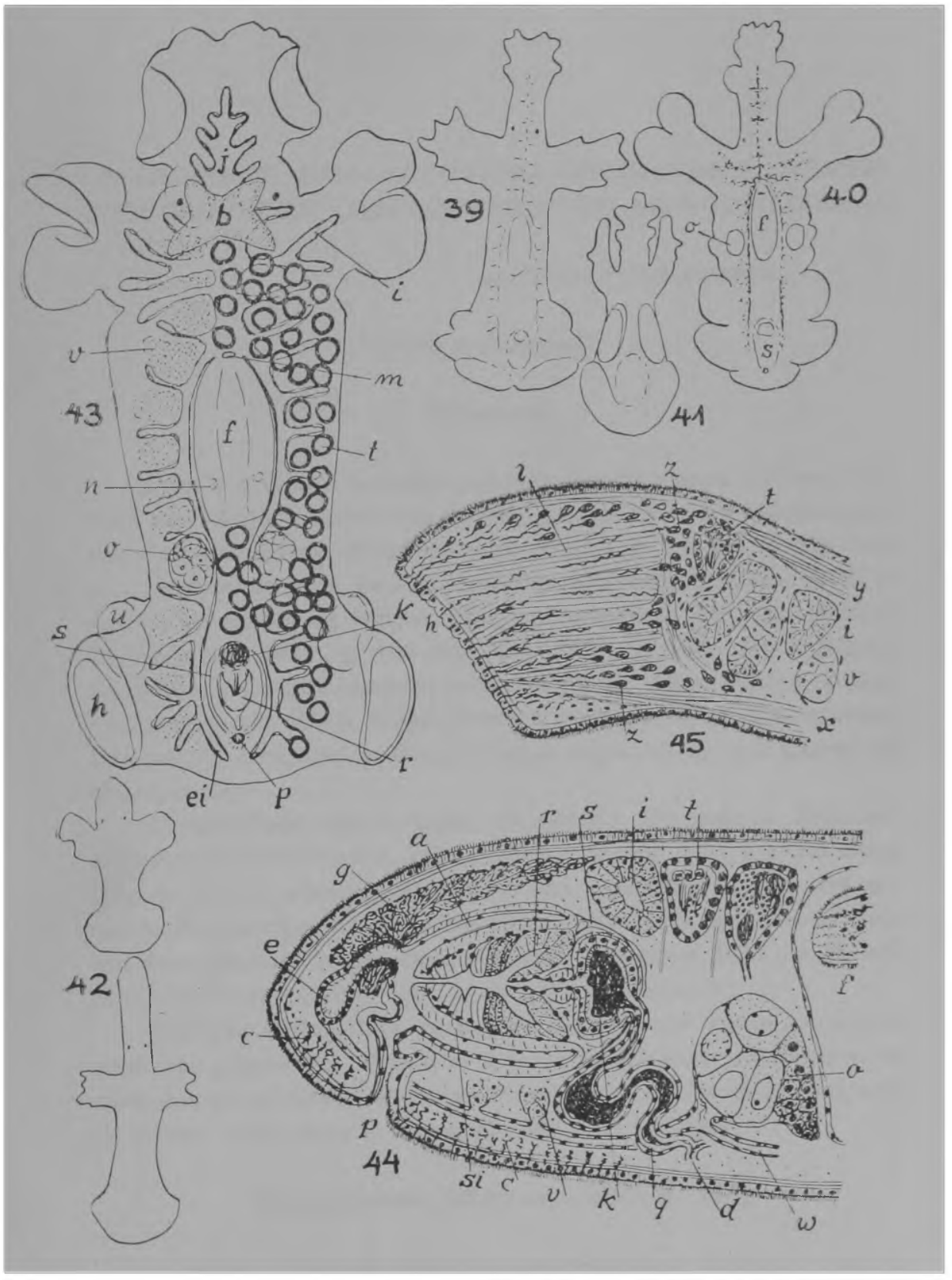


